號一十五百三第誌雜會究研事醫堂天順 六O二

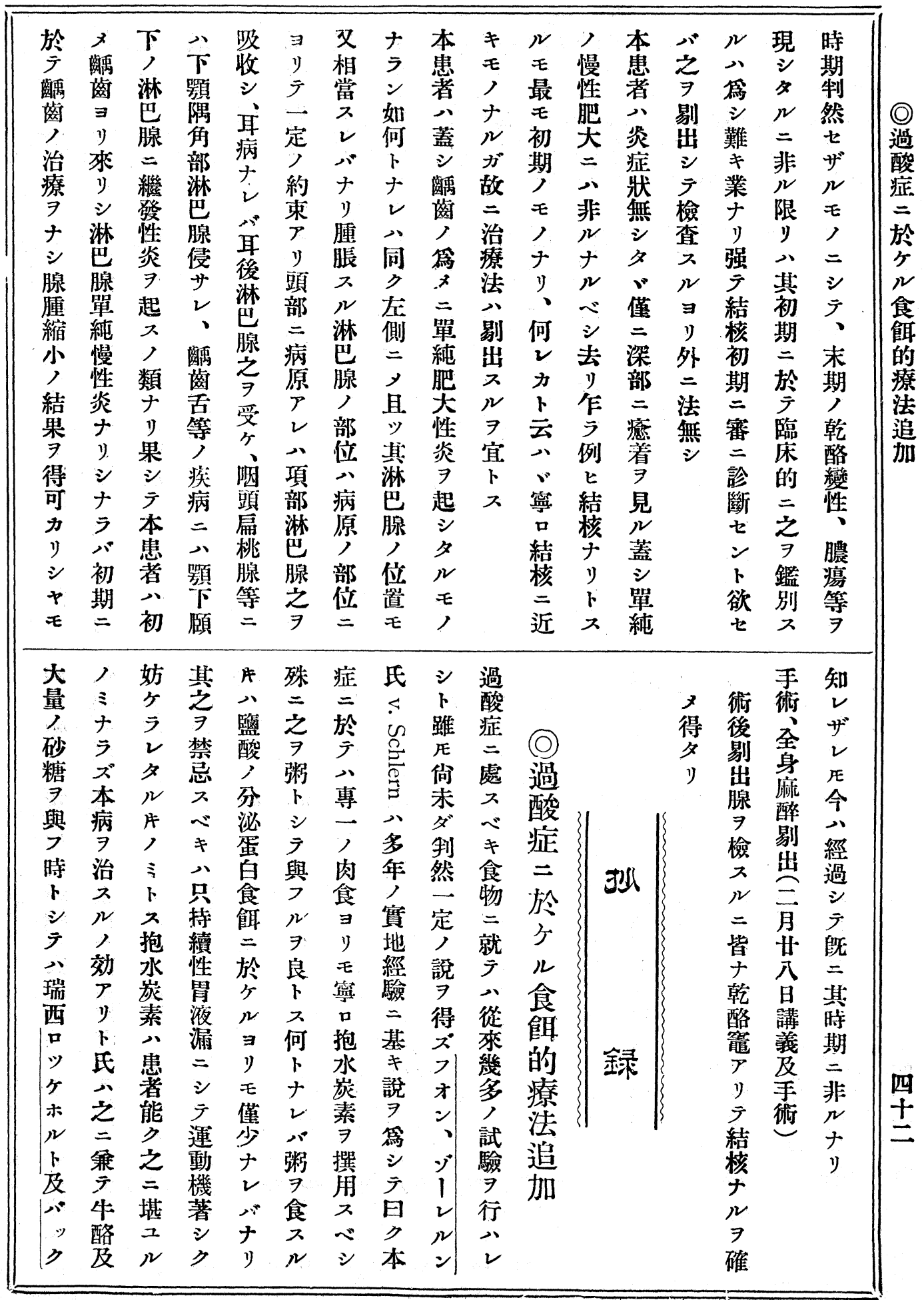


七0二錄抄誌雜會究研事醫堂天順

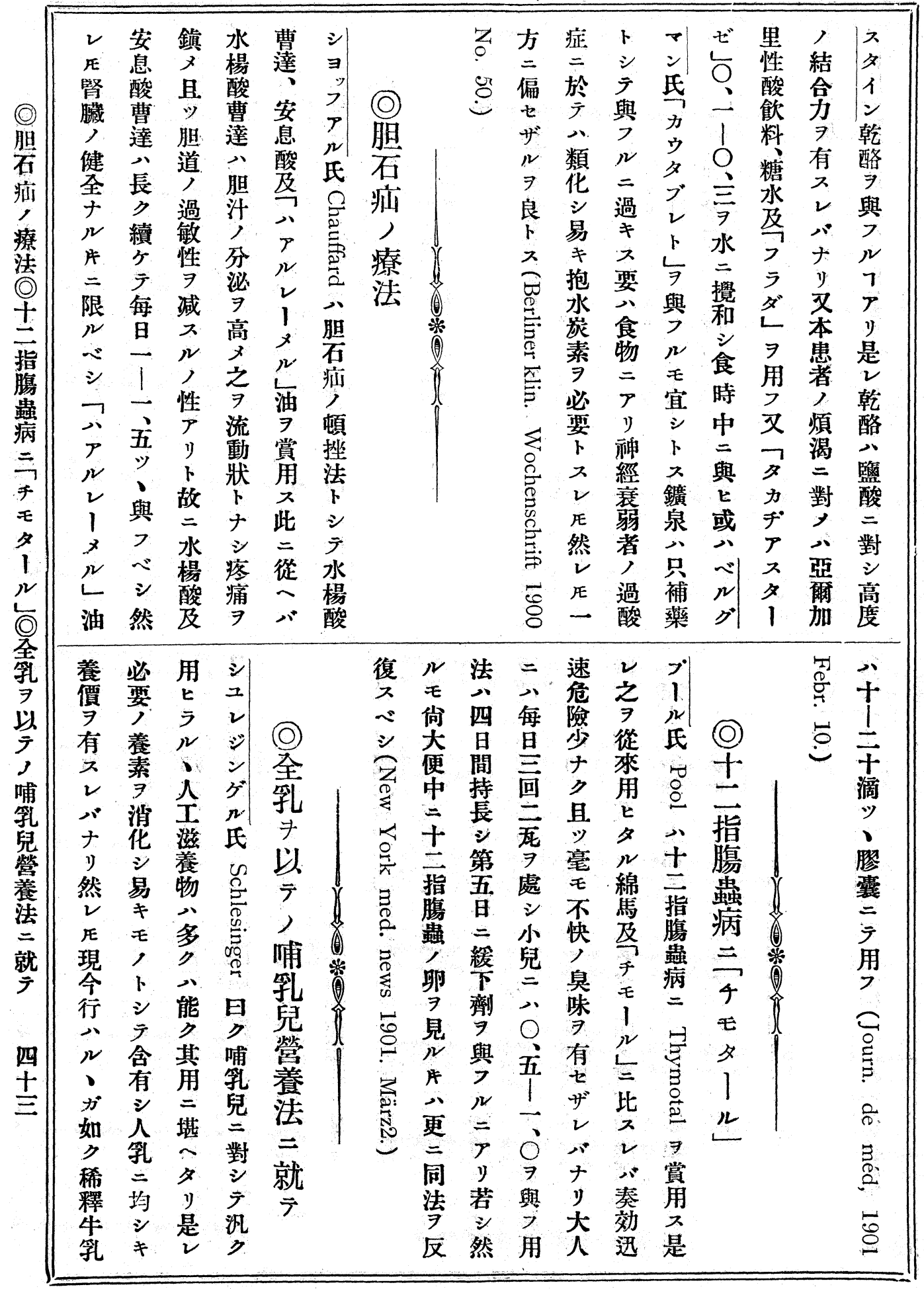


號一十五百三第誌雜會究研事醫堂天順 $八 0$ 二

\begin{tabular}{|c|c|c|c|c|c|c|c|c|c|c|c|c|c|c|c|c|}
\hline > & |ギ & & & & $\xi$ & $=$ & $N$ & 代 & N & 少 & U & 物 & ナ & $\exists$ & ズ & 7 \\
\hline 內 & $\simeq$ & & & & 8 & 適 & ガ & 不 & 稀 & $=$ & $\exists$ & $=$ & $N$ & 得 & 何 & 以。 \\
\hline 腦 & Ł & & & & $\overrightarrow{8}$ & 當 & 故 & 可 & 糬 & 過 & 得 & 由 & 液 & 2 & 1 & $\bar{y}$ \\
\hline 水 & 2 & & (0) & & 密 & 思 & $=$ & + & Ł & ₹ & ザ & $\bar{z}$ & 量 & 7 & + & 哺 \\
\hline 腫 & 醫 & 療 & 内 & & $\stackrel{\varrho}{\Xi}$ & 其 & 조 & y) & ザ & $\pi$ & U & 得 & $\exists$ & 極 & 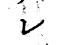 & 乳 \\
\hline 7 & 學 & 準 & 胹 & & & 兒 & 孚 & 蓋 & $N$ & 彼 & カ & 夕 & 體 & $\bar{\gamma}$ & バ & 兒 \\
\hline 起 & 會 & 佁 & 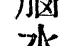 & & 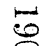 & 量 & 營 & シ & 4 & Y & 故 & 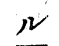 & 外 & 少 & 稀 & $\exists$ \\
\hline 七 & $=$ & $=$ & 水 & & 임 & $\gamma$ & 薞 & 4 & 乳 & 小 & $=$ & $\neg$ & $=$ & t & 釋 & 養 \\
\hline ル & 於 & 就 & 腫 & & & 死 & 法 & 乳 & $\exists$ & 兒 & 身 & $x$ & 排 & $\Rightarrow$ & Ł & 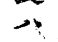 \\
\hline 小 & $\bar{j}$ & च & 及 & & 2. & 數 & $\therefore$ & $\therefore$ & L & 萎 & 體 & $\begin{array}{l}f \\
N\end{array}$ & 拈 & 或 & $N$ & メ \\
\hline 腦 & ゾ| & & 小. & \& & $-T$ & $\exists$ & 最 & 人 & $\bar{J}$ & 縮 & $>$ & $\begin{array}{l}\text { ル } \\
\text { ギ }\end{array}$ & セ & > & 4 & $r$ \\
\hline 腫 & 么 & & & (1) & & 减 & 廉 & 乳 & 小 & , & 保 & $\mathfrak{j}$ & $y$ & 水 & 乳 & セ \\
\hline 瘍 & $\not$ & & 煞 & 洁 & & x & 佂 & ト & 兒 & 原 & 存 & $L$ & $\vdash$ & 分 & $\Rightarrow$ & > \\
\hline , & $\pi$ & & 腫 & (1) & & $N$ & 最 & 同 & $=$ & 园 & 及 & 9 & 欲 & 多 & 以 & 此 \\
\hline- & 氏 & & $\begin{array}{l}\text { 能 } \\
\text { 疸 }\end{array}$ & $\pi$ & & $=$ & 簡 & - & 不 & $\therefore$ & 發 & 此 & Ł & $\neq$ & $\bar{\gamma}$ & 1 \\
\hline 例 & in & & 㻛 & & & 足 & 便 & 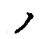 & 渻 & 實 & 管 & 過 & バ & $=$ & 養 & 如 \\
\hline 7 & ${ }_{B}^{\circ}$ & & $>$ & & & $\pi$ & + & $\neg$ & 化 & $=$ & $=$ & 度 & 小 & 過 & 7 & $\neq$ \\
\hline 委 & $\frac{8}{3}$ & & 診 & & & $r$ & $N$ & 力 & 广 & 此 & 餘 & $F$ & 兒 & 7 & 半 & 羪 \\
\hline$\dot{y}$ & $\stackrel{乛 ్}{\oplus}$ & & 㜅 & & & & $\exists$ & 口 & y & $=$ & ㅈ. & 2 & , & $v$ & $\therefore$ & 宿 \\
\hline$\Rightarrow$ & & & 㽘 & & & 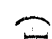 & 以. & y & F & $\gamma$ & 所 & 健 & 身 & 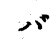 & 哺 & $\exists$ \\
\hline 㪕 & $\rightarrow$ & & 奴 & & & 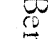 & $\bar{J}$ & ᄂ & ᄌ & y & $\rightarrow$ & 役 & 體 & ナ & 乳 & 得 \\
\hline 告 & 先 & & 治 & & & $\Xi$ & 特 & 量 & $N$ & $\bar{Y}$ & 極 & $=$ & $\rightarrow$ & y & 兒 & $N$ \\
\hline セ & \% & & & & & & $=$ & $\Rightarrow$ & 者 & 存 & $x$ & 慗 & 其 & 此 & $\rightarrow$ & 7 \\
\hline y & 高 & & & & & $\bar{\Xi}$ & 貧 & 有 & $\bar{\gamma}$ & x & $\bar{Y}$ & 少 & 滋 & 過 & 養 & 能 \\
\hline 其: & 度 & & & & & $\vec{\Xi}$ & 民 & x & 2 & 或 & 僅 & $\therefore$ & 養 & 紊 & 储 & $\rightarrow$ \\
\hline 教 & 七 & 作 & 水 & יד & 時 & $\sqrt{8}$ & $T_{0}$ & $=$ & シ & ג & 减 & $\gamma$ & 呈 & $\nu$ & + & 孺 \\
\hline 授 & シ & r & 腫 & 左 & 期 & 射 & 肢 & モ & 夕 & 分 & シ & $y$ & シ & $=$ & - & 侯 \\
\hline$\therefore$ & $=$ & 時 & $\exists$ & 小 & $\Rightarrow$ & $\rightarrow$ & , & 發 & $y$ & 開 & 其 & $\neq$ & 聅 & 従 & 歲 & 次 \\
\hline 保 & 由 & $\exists$ & 併 & 腦 & 期 & 缺 & 輕 & シ & $\neq$ & 斜 & 他 & 眼 & 䜿 & t & ) & 3 \\
\hline デ & $N$ & 期 & 發 & 平 & シ & 如 & 塺 & 又 & 時 & 視 & 最 & 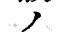 & 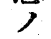 & 加 & 童 & 如 \\
\hline$=1$ & $E$ & シ & セ & 球 & テ & シ & , & 右 & 今 & 及 & 初 & 陻 & 經 & Z & 發 & 政 \\
\hline$\rightarrow$ & ノ & テ & $w$ & $J$ & 發 & $\neq$ & 瘘 & 5 & 左 & 右 & $\rightarrow$ & 害 & 滆 & 眩 & 作 & \\
\hline イ & ト & 發 & $E$ & 上 & $\pi$ & 此 & 蒻 & 膊 & 側 & 牢 & 不 & $\rightarrow$ & 䒘 & 量 & 性 & \\
\hline 1 & シ & x & ノ & 部 & $N$ & 等 & $=$ & $=$ & $J$ & 3 & 定 & 보 & $=$ & $\exists$ & $=$ & \\
\hline 2 & $\bar{\gamma}$ & $n$ & $r$ & $=$ & $=$ & J & 筆 & モ & $\equiv$ & 結 & j & 朝 & 前 & 發 & 發 & \\
\hline 氏 & 說 & $\rightarrow$ & 想 & 腄 & 泩 & 症 & $\bar{z}$ & 疼 & $\overline{\mathbf{X}}$ & 合 & 右 & $\exists$ & 频 & $\pi$ & $\pi$ & \\
\hline z & 明 & 恐 & 像 & 瘍 & 意 & 候 & 䖺 & 痛 & 神 & 性 & 側 & リ & נ) & $N$ & $N$ & \\
\hline 7 & $\pi$ & $\eta$ & 七 & $\exists$ & x & $\exists$ & $\neq$ & $\exists$ & 經 & 偏 & 外 & 現 & 隆 & $=$ & 頭 & \\
\hline 手 & へ & $\rightarrow$ & ラ & 生 & べ & リ & $\neg$ & 發 & 領 & 斜 & 轉 & $\infty$ & 起 & 至 & 痛 & \\
\hline 術 & 力 & $カ^{\prime}$ & $v$ & 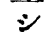 & $\Rightarrow$ & 局 & $\gamma$ & I & $=$ & $\Rightarrow$ & 蓣 & $v$ & $>0$ & $\bar{v}$ & $=$ & \\
\hline t & y & 1 & タ & テ & 陑 & 處 & 名 & \& & 疼 & 猍 & 經 & 視 & 更 & $y$ & 䇦 & \\
\hline シ & キ & 2 & y & 在 & $y$ & 診 & ") & y & 痛 & シ & 瘞 & 力 & $=$ & 頭 & $\bar{z}$ & \\
\hline 牛 & & ע & $\neq$ & 橋 & 概 & 铲 & $\neq$ & $\neq$ & $\Rightarrow$ & 筝 & 穿 & $\rightarrow$ & 增 & ) & 听嵒. & \\
\hline$\rightarrow$ & & 氏 & 其 & $\exists$ & 察 & $\Rightarrow$ & ע & 比 & 發 & $\bar{y}$ & $\exists$ & 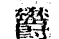 & 加 & 形 & 姓 & \\
\hline 毫 & & 大 & 前 & 涯 & 的 & $T^{\circ}$ & 1 & 較 & 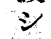 & 眼 & 呈 & Ifil & 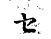 & $\rightarrow$ & $\overline{7}$ & \\
\hline 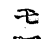 & & 㓩 & 記 & 迫 & 䛦 & x & 7 & 的 & 稀 & 球 & t & 孚 & $v$ & 腦 & 患 & \\
\hline 腄 & & 脈 & 顧 & シ & 衒 & $=$ & 發 & $=$ & $=$ & 震 & シ & 昰頁 & ガ & 水 & $\mathrm{E}$ & \\
\hline 瘍 & & $\Rightarrow$ & 攔 & 金 & $r$ & 特 & シ & 晚 & $>$ & 璗 & モ & 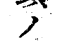 & 如 & 腄 & 日 & \\
\hline 7 & & 壓 & 狀 & $\bar{\jmath}$ & ) & $=$ & 膝 & $\Rightarrow$ & 右 & $\Rightarrow$ & 後 & 䉆 & $\neq$ & 狀 & 7 & \\
\hline 見 & & 迫 & 發 & 腦 & テ & 其: & 蓋 & 兩 & 側 & 來 & $=$ & $=$ & 咸 & 笋 & 經 & \\
\hline
\end{tabular}


九○二錄抄誌雜會究研事醫堂天順

(a)

內

腦

水

及

小

脑

腫

瘍

診

急

及

治

療

法

就

テ

是 $テ \exists \eta$ 腦 腦 $=>$ 開モも四側火小 ザ

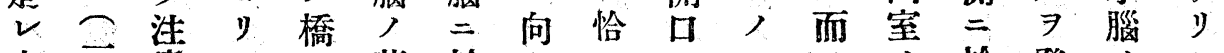

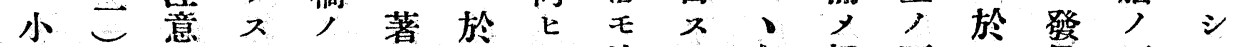
腦腦 $ン 、$ 左 $シ$ 小第 $心$ 如橋天見正卜

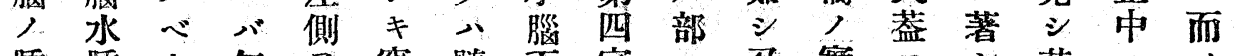

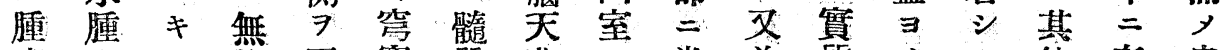

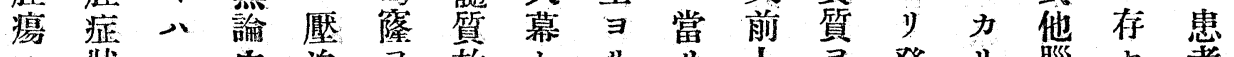

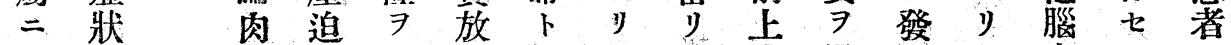

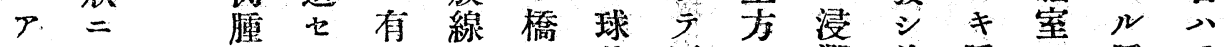

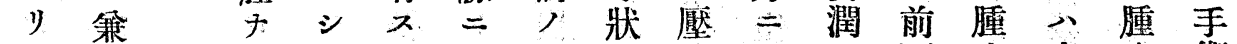

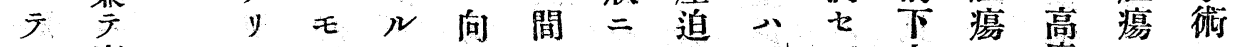

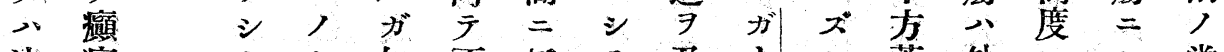
决癎 ナ $卜$ 如兩括 $\overline{3}$ 及 シ 性り七ク側入其ボレテ形觀撗テ夜 テ症其ザ右烡シ 後七ン橋窩上張而二

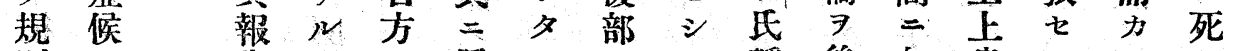

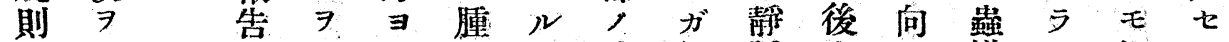

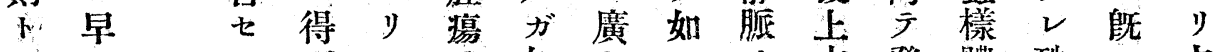
ナ ラ ズ 入 發 レ

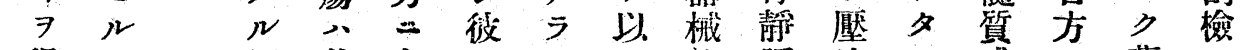
得 $=$ 例其向 $y=\bar{y}$ 的秛迫几或 $\exists$ 蔓

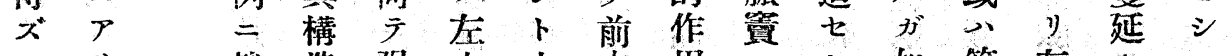
y. 就造强小势用 $= \pm$ 如第左七

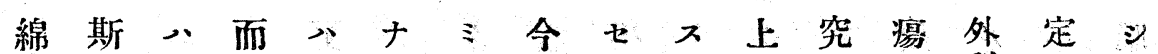

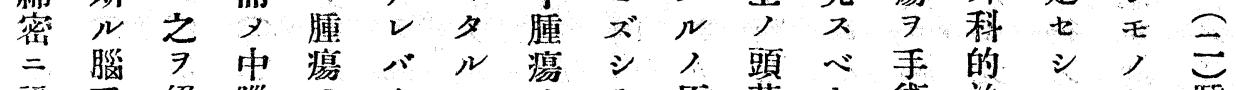
說手絕腦 $\ni$ 十

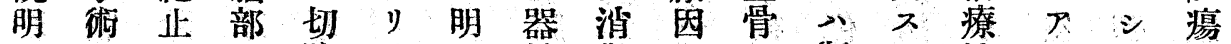

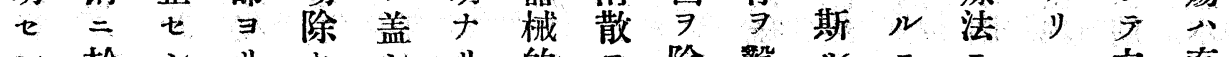
ン於 $シ$ 少

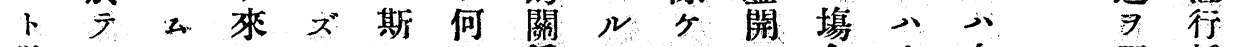

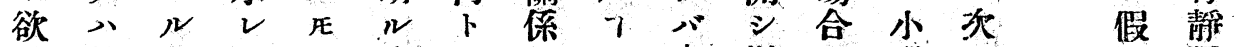

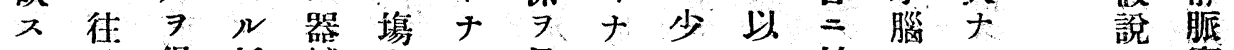

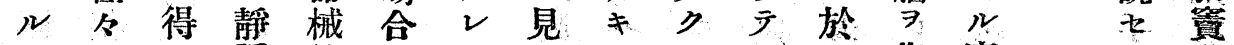
牛死心眽的

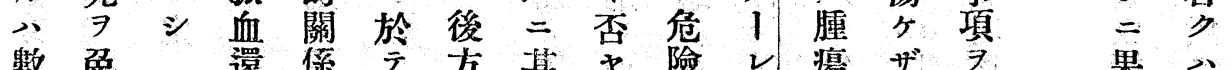

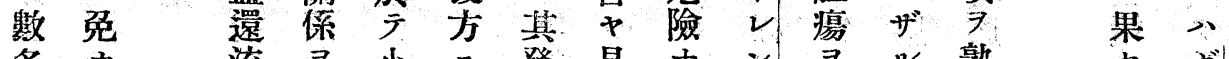

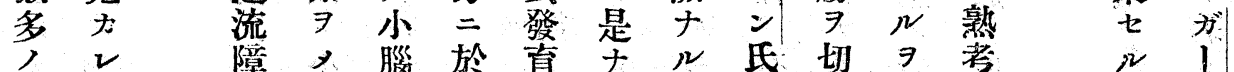
四㷪 $x^{*}$ 礙 著部々 ス y 腦静 除得

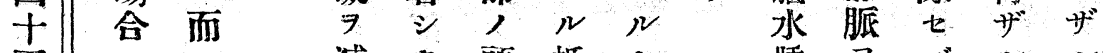

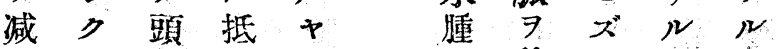
於此筫蓋抗前 $\bar{y}$ 死 一 2 2 3 頗 種原公開少向 固园力べク强テ 有 $习$ 或 为大進 $\rightarrow$ 後 $シ 7$

腦 方 方 故 得 室 $\exists$ 小 $=$ ス $\exists$ 》腦 茲 即 穿塺部 $三$ 千 力 2 文 解 註 剖静 $=7$ 之 壓 刺迫)講踵 学迫 確 セ 
號一十五百三第誌雜會究研事醫堂天順 O-二

\begin{tabular}{|c|c|c|c|c|c|c|c|c|c|c|c|c|c|c|c|c|}
\hline 入 & 閉 & 腫 & 的 & $r$ & 然 & 術 & テ & 腦 & 漸 & 因 & 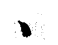 & 腫 & 尙 & 痬 & 輕 & ナ \\
\hline ん゙ & 塞 & $\exists$ & 位 & $p$ & $v$ & 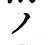 & 本 & $\exists$ & 進 & $\rightarrow$ & $=$ & 汮 & 且 & 手 & 微 & $N$ \\
\hline シ & $\exists$ & 伴 & 置 & 固 & 庄 & 成 & 手 & t) & 性 & 此 & 由 & $\exists$ & 忽 & 術 & $=$ & 事 \\
\hline & 假 & $\sim$ & $\exists$ & $\exists$ & 此 & 績 & 術 & 自 & 值 & $=$ & $\sim$ & 俄 & 然 & $=$ & シ & 實 \\
\hline & 定 & 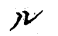 & リ & y & 二 & $\uparrow$ & $\overparen{\text { 告 }}$ & ラ & 接 & 存 & $r$ & $=$ & 頓 & 於 & テ & $=$ \\
\hline & 七 & 小 & 觀 & 言 & 時 & 更 & 里里 & 血. & 麻 & ス & セ & 切 & 死 & $\bar{\gamma}$ & 其 & 際 \\
\hline & ザ & 腦 & 察 & $\exists$ & 的 & $=$ & 場 & 行 & 獏 & 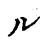 & ザ & 除 & $\Rightarrow$ & $\therefore$ & 死 & 會 \\
\hline & 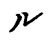 & 腫 & シ & 俟 & 手 & 大 & 墥 & $\exists$ & $=$ & 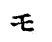 & ル & ス & 免 & 腫 & 畐 & $\pi$ \\
\hline & 7 & 瘍 & テ & タ & 術 & $=$ & 㨄 & 整 & 原 & , & 7 & 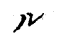 & 力 & 痬 & 7 & べ \\
\hline & 得 & 及 & 大 & ズ & タ & 佳 & 出 & 理 & 因 & ト & 得 & $\nabla$ & $v$ & ر & 之 & シ \\
\hline & ザ & 他 & $=$ & 只 & $N$ & 良 & tan & $\pi$ & z & 第 & $x^{\prime}$ & 諸 & ザ & 診 & $=$ & 即 \\
\hline & $N$ & 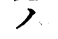 & 賛 & 斯 & 惥 & F & 邚 & $N$ & 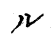 & $\pi$ & 腦 & 般 & 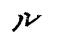 & 颜 & 歸 & F \\
\hline & 牛 & 腦 & 間 & $\eta$ & 者 & ナ & 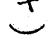 & ᄀ & 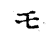 & べ & 手 & ノ & 7 & 說 & $\pi$ & 外 \\
\hline & $\therefore$ & 水 & $\exists$ & シ & $=$ & $N$ & 7 & 昵 & ノ & ク & 術 & 血 & $\therefore$ & ラ & 可 & 科 \\
\hline & 左. & 腫 & 表 & テ & $E$ & 7 & 行 & $\gamma$ & ナ & 而 & 後 & 行 & 往 & ス & 力 & 手 \\
\hline & J & $=$ & 七 & 手 & 外 & 7 & 7 & ラ & リ & $y$ & $=$ & 關 & \& & 其 & ラ & 術 \\
\hline & 順 & , & ザ & 術 & 科 & 得 & 7 & シ & 若 & 臨 & 死 & 係 & 之 & 手 & ザ & ノ \\
\hline & 序 & ガ| & $\pi$ & 七 & 醫 & V & $\exists$ & $x$ & シ & 床 & X & $E$ & $\bar{\gamma}$ & 術 & N & 值 \\
\hline & $=$ & 1 & $\Rightarrow$ & バ & $=$ & & 得 & 且 & 頭 & 的 & $N$ & 圣 & $N$ & 本 & 7 & 接 \\
\hline & 㑈 & 2 & 得 & 之 & E & & t & ツ & 荅 & 症 & $E$ & 然 & 所 & 䅡 & 是 & 結 \\
\hline & $\bar{\gamma}$ & ข| & ズ & $\exists$ & 大 & & シ & 一 & 腔 & 䐅 & ' & 變造 & $=$ & $=$ & ナ & 果 \\
\hline & 手 & 氏 & 故 & 神 & $=$ & & $x$ & $=$ & 切 & 八 & , & 化 & シ & 過 & y & $\therefore$ \\
\hline & 術 & 静 & $=$ & 經 & 不 & & バ & 週 & 開 & 延 & 多 & 七 & $\bar{\gamma}$ & グ & 殊 & 極 \\
\hline & $\exists$ & 脈 & 腦 & 病 & 便 & & 腦 & 7 & 後 & 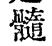 & $\neq$ & $\bar{ラ}$ & 是 & ע & $=$ & $\not$ \\
\hline & 施 & 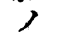 & 水 & 學 & ナ & & 手 & 經 & $=$ & 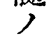 & 原 & N & $v$ & $モ$ & 腄 & $\bar{\gamma}$ \\
\hline 甚 & 腦 & $=$ & $ル$ & 故 & シ & モ & テ & 學 & 右 & タ & シ & 更 & & ス & & \\
\hline 夕 & 水 & 後 & 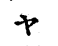 & $=$ & 厶 & 腦 & 盖 & 的 & $\rightarrow$ & y & $\bar{\gamma}$ & $=$ & $\cong$ & 壓 & $\stackrel{=}{=}$ & I \\
\hline 多 & 腫 & 方 & 先 & 神 & $M$ & 室 & シ & 適 & 腦 & & 血. & 腦 & $\Xi$ & 迫 & 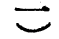 & \\
\hline$\neq$ & ノ & $=$ & ツ & 經 & $\therefore$ & 手 & 單 & 應 & 水 & & 行 & 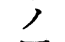 & 出 & $\bar{F}$ & 小 & 出 \\
\hline 腦 & 初 & 空 & 小 & 病 & 俄 & 術 & - & ナ & 垕 & & ر & 壓 & 來 & 除 & 腦 & 來 \\
\hline 水 & 期 & 地 & 腦 & 學 & 然 & 後 & ノ & y & $\exists$ & & 關 & 迫 & 得 & 却 & $>$ & 得 \\
\hline 腫 & $=$ & $\exists$ & $=$ & 的 & 腦 & $=$ & 脑 & ト & 伴 & & 係 & $\exists$ & ぶ & x & 後 & べ \\
\hline 性 & 良 & 生 & 該 & $=$ & 壓 & 延 & 水 & 雖 & 發 & & 7 & 去 & $\eta$ & べ & 部 & $\eta$ \\
\hline 癡 & 好 & ズ & 當 & 論 & 迫 & 䯣 & 腫 & $\mathbb{E}$ & Ł & & 恢 & N & ン & シ & 1 & $\nu$ \\
\hline 呆 & , & $v$ & ス & ス & I & , & $=$ & 此 & $N$ & & 復 & べ & バ & 而 & 頭 & バ \\
\hline 者 & 手 & バ & $\nu$ & $v$ & 去 & 血. & E & >V & 喱 & & 七 & シ & 腫 & $y$ & 葐 & 腰 \\
\hline 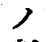 & 術 & ナ & 頭 & バ & N & 行 & 適 & 是 & 瘍 & & シ & 是 & 瘍 & - & 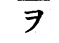 & 髓 \\
\hline 數 & 成 & ? & 蒏 & 中 & ガ & 障 & 應 & $v$ & ノ & & 後 & $v$ & 7 & 定 & 切 & 穿 \\
\hline 7 & 績 & 若 & 腔 & 腦 & 第 & 碍 & x & 獨 & 手 & & ナ & 預 & 摘 & $\nearrow$ & 開 & 刺 \\
\hline 著 & 7 & シ & $\exists$ & $J$ & ナ & $\exists$ & $N$ & $y$ & 術 & & $N$ & $x$ & 出 & 時 & シ & 法 \\
\hline シ & 擧 & 果 & 開 & 䝑 & リ & 來 & 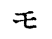 & 該 & $=$ & & 7 & 小 & シ & 日 & ガ & \\
\hline$\eta$ & ケ & シ & $n$ & 脈 & $r$ & シ & , & 症 & 就 & & 以 & 腦 & 若 & 7 & 1 & \\
\hline 减 & 得 & $\bar{\gamma}$ & $\exists$ & 樊棿 & セ & テ & ナ & $=$ & $\bar{\gamma}$ & & テ & 部 & $\eta$ & 經 & $v$ & \\
\hline$\pi$ & タ & 此 & 要 & 汫 & ザ & 不 & ラ & ノ & 論 & & 零 & $j$ & $>$ & $\bar{J}$ & シ| & \\
\hline ル & $y$ & 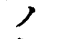 & $\pi$ & $\exists$ & $\sim$ & 幸 & ン & $\Sigma$ & シ & & シ & 頭 & 䐉 & & 氏 & \\
\hline 7 & ト & 如 & 是 & 去 & 7 & 1 & 此 & 止 & タ & & 得 & 薈 & 窒 & & 埆 & \\
\hline 7 & Ł & $\eta$ & $v$ & ラ & 得 & 轉 & 症 & $\checkmark$ & 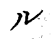 & & べ & 腔 & 7 & & 脈 & \\
\hline 得 & 八゙ & $=$ & 之 & ン & ズ & 歸 & $=$ & ラ & 神 & & $\neq$ & 7 & 穿 & & $=$ & \\
\hline$N$ & 彼 & シ & ガ & ト & & $\boldsymbol{T}$ & 於 & ズ & 經 & & ノ & 切 & 刺 & & 及 & \\
\hline$=$ & ノ & テ & 篇 & $\pi$ & & ラ & $\overline{\bar{\gamma}}$ & シ & 病 & & 7 & 開 & シ & & ボ & \\
\hline
\end{tabular}




\section{一一二 錄抄誌雜會究研事醫堂天順}




號一十五百三第誌㩁會究研事醫堂天順 二一二

亏無中シ

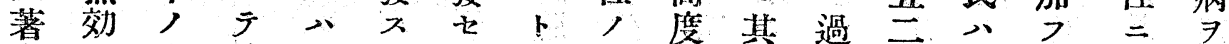

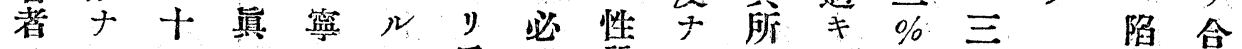

モ $ハ$ ，

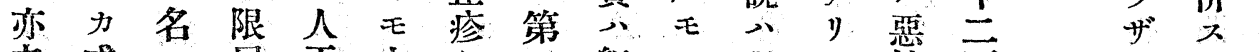

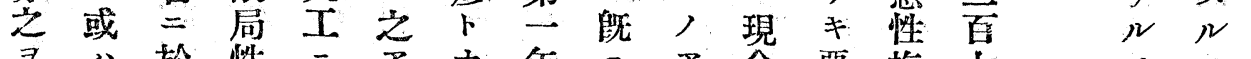

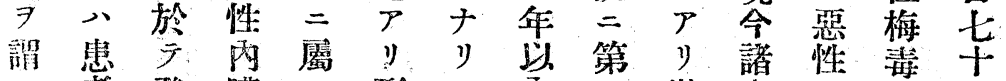

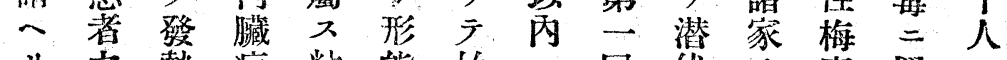

y之熱 症粘態始二回伏, 毒躍,

沃 $三$ 候膜學 $、$ 墢人期說 $=\nu$ 男

造堪

加乞二稀牀其 $尹$ 但疹甚大学 $\exists$ 梅

里 ズア 有

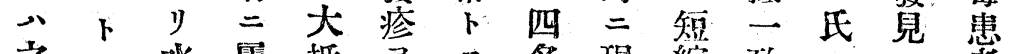

之八水屬抵 $习$ 名現縮致一言者

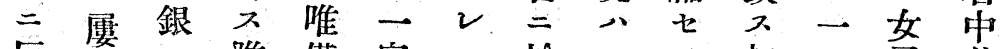

反管空唯僅定 $氏$ 於

聞惡奇 $=>$ 護 $\bar{J}$ 或 $ル$ 發 $\vec{\gamma}$

天性ナ發部謨 、可症說於七

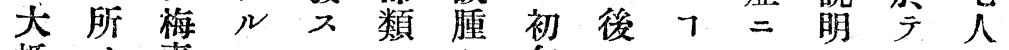

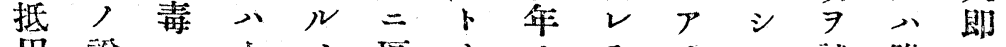

用說

可二於歺三別 y 終 飞其特ミ石

モ $モ$

ノ)

$\rightarrow$ 或

低疾

ス 患

七高

度

此 三

二 進

從邓

七N

艺 E

重 未

症 多

梅 䇎

毒 〉

二 惡

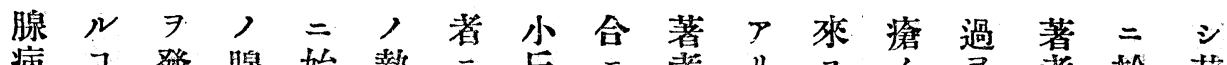

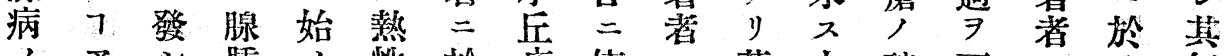

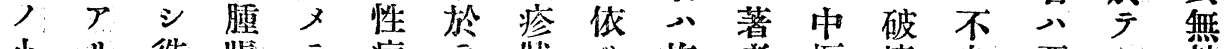

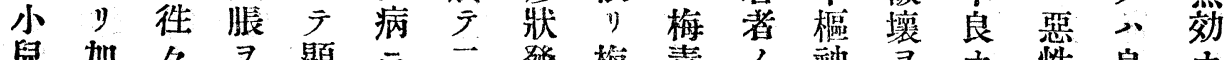

兒 加 $尹$ 顯二三發檴毒, 神

八答化有著於重疹毒々惡經桃亏梅效

後兒膘ス

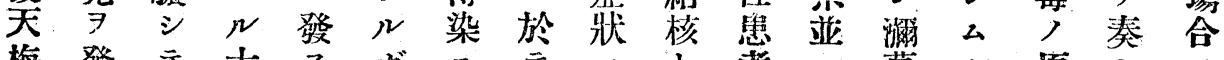

梅發

毒音强人如只肺了中酒性諧因他今

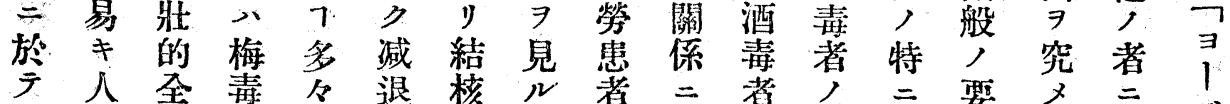

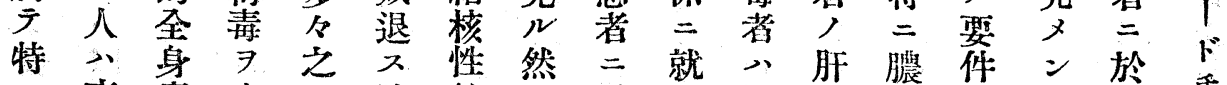

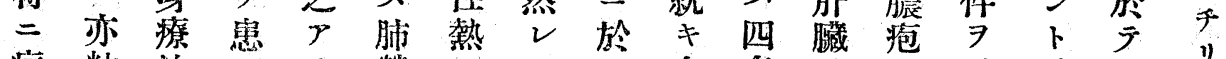

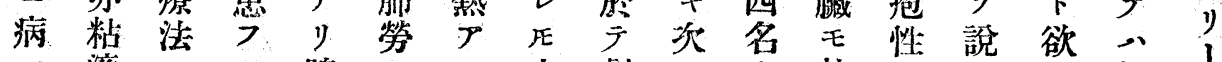

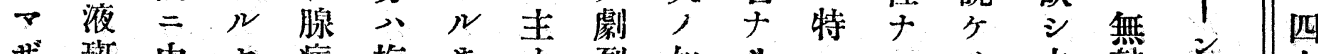

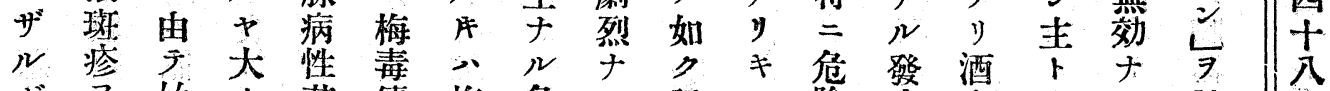

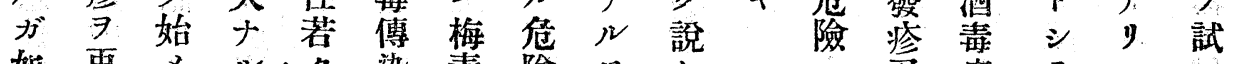

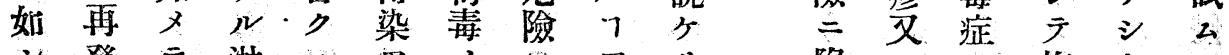

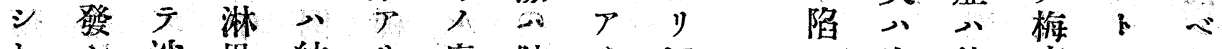

卜

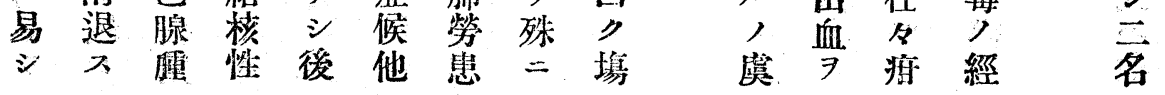


三一二 錄抄誌雜會究研事醫堂天順

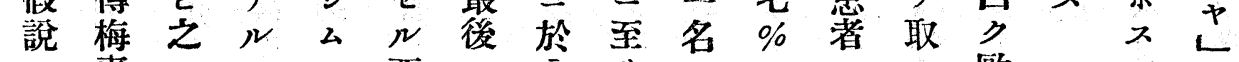

ス毒加，發上著八又二十著，說

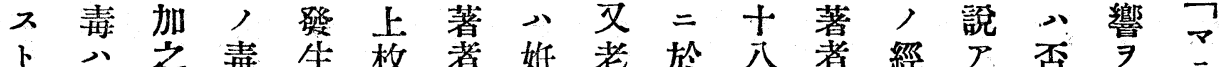
八毒 $\exists=N$ 要 $=\bar{J} \cdots \cdots=ル$ 歐

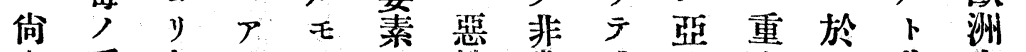

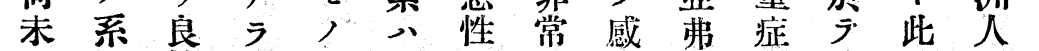

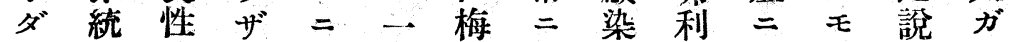

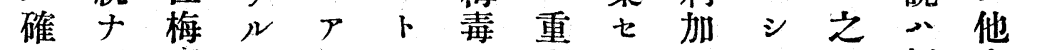
ナキ毒フラシノ症ルシラョ經人 ラ 家 $、$ ザテ 真ナ梅 於五確 驗 種

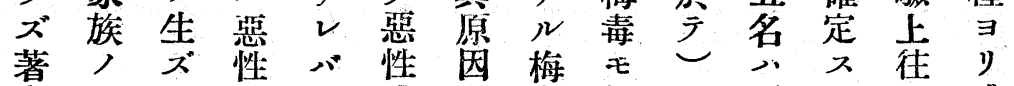
者人ル梅十或 $\ni$ 毒經 惡 八二 = 毒》心論, 過性モ主染 一傳由 由 其重議發不 ナ, 張

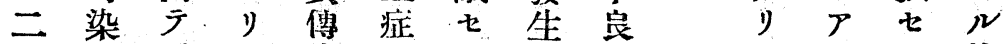

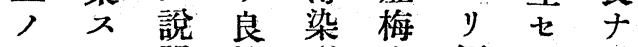
人ル明性 素毒何 ルN

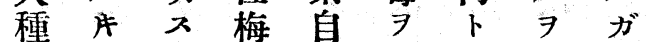
つ惡 ゙゙ 毒 個 規ナ見 如 特 性 $シ \quad \exists=$ 則 $v$ 夕 二 三文來 特 的 バリ著 日 變 梅 別二以卜者

キ リ ラ 梅 即 ル毒 四于、入 名 患所 特 七 不 八者ナ二 良 東

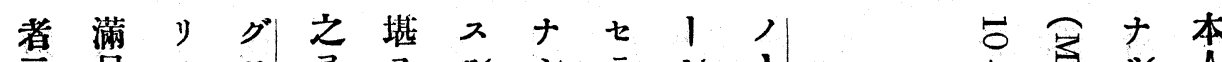
立足 多結

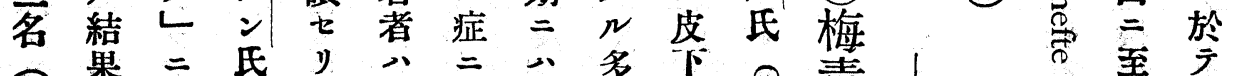

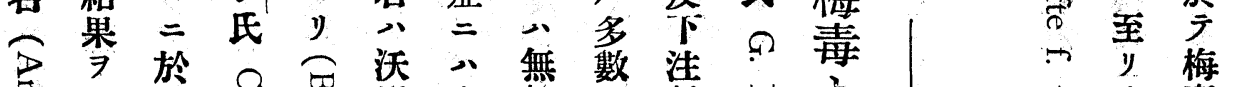

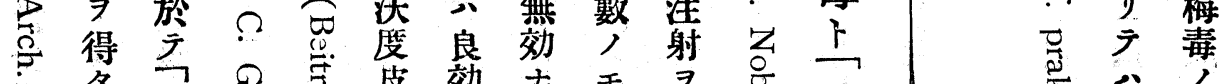

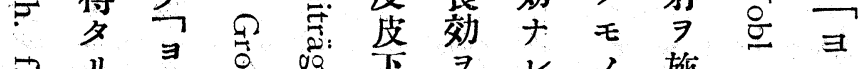
$\rightarrow$ 当

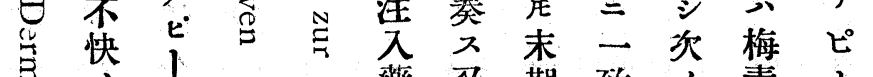
沓人

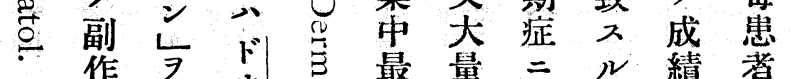
组用內 ウ 总最量

四 总用丙 全莡 、 \& E 射度少名

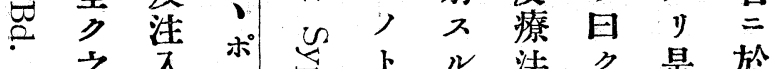

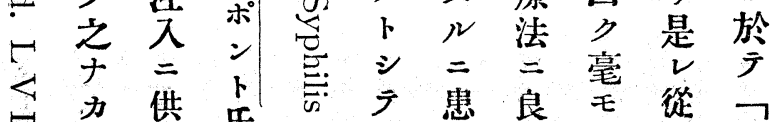

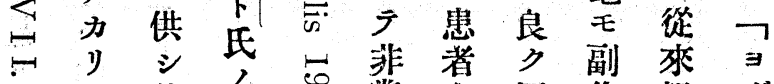

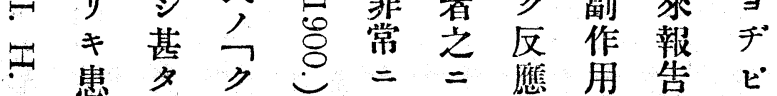




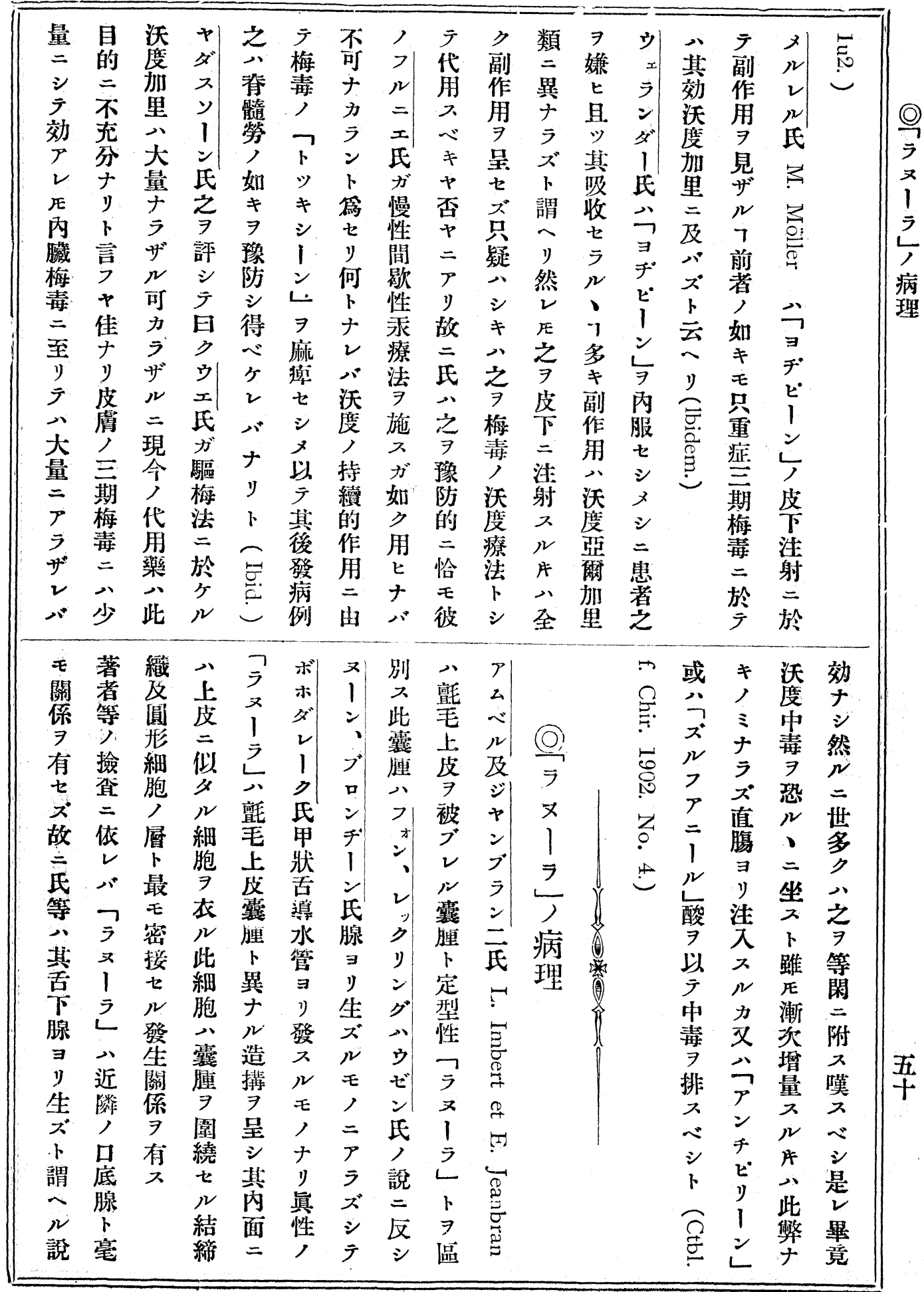




\section{五一二錄抄誌雜會究研事醫堂天順}

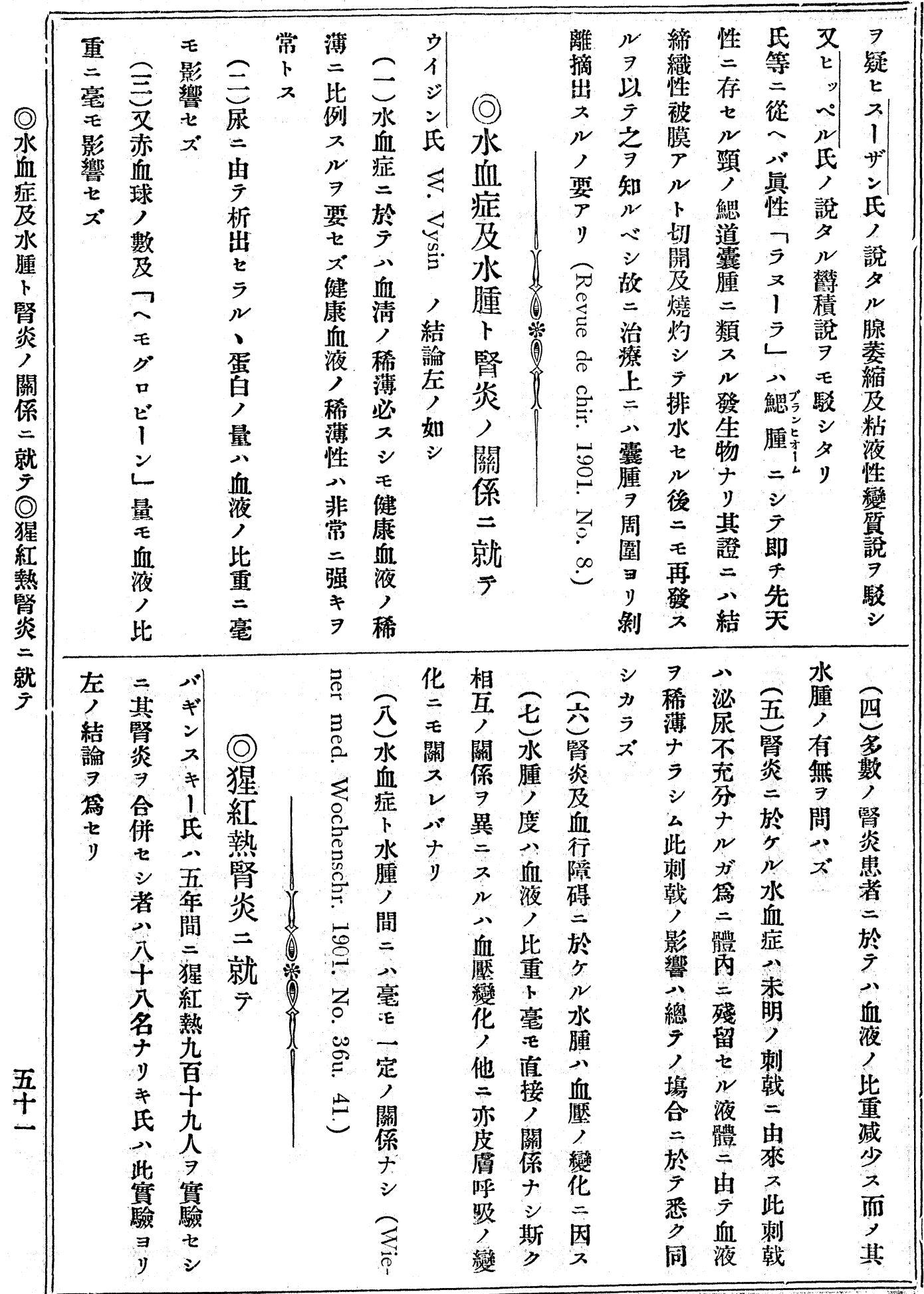


號一十五百三第誌雜會究研事醫堂天順

\begin{tabular}{|c|c|c|c|c|c|c|c|c|c|c|c|c|c|c|c|c|}
\hline 猩 & シ & 續 & 合 & 區 & 其 & ע & $=$ & 7 & 绝 & 㷁 & 5 & ス & $N$ & + & $=$ & 猩 \\
\hline 紅 & テ & ; & 併 & 别 & 他 & & $\boldsymbol{\gamma}$ & 不 & 9 & 後 & 2 & $N$ & 另 & シ & 發 & 紅 \\
\hline 熱 & II & テ & 症 & 入 & 猩 & & リ & 良 & 呈 & 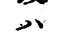 & バ & 時 & 如 & 即 & $\pi$ & 熱 \\
\hline 腎 & 證 & 慢 & $\exists$ & べ & 紅 & & テ & J & $\pi$ & 蛋 & 豫 & 期 & $\neq$ & F & 㹂 & 㹂 \\
\hline 炎 & シ & 性 & 除 & シ & 濕 & & 此 & 徵 & $N$ & $\vec{\theta}$ & 後 & $=$ & 者 & 重 & 炎 & 炎 \\
\hline 自 & タ & 蛋 & 5 & 八 & 㹂 & & 尿 & F & 尿 & 尿 & 不 & 關 & $\mathcal{E}$ & 症 & 3 & $\rightarrow$ \\
\hline 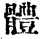 & y & 白 & バ & 十 & 炎 & & 毒 & ナ & $\therefore$ & 及 & 良 & 係 & 蛋 & 猩 & 發 & 必 \\
\hline$>$ & $\neq$ & 尿 & 六 & 八 & $\therefore$ & & 症 & シ & 其 & 血. & 于 & Ł & 百 & 紅 & 生 & ス \\
\hline 如 & & $\Rightarrow$ & 名 & 名 & 之 & & $\therefore$ & $\bar{\gamma}$ & 樵 & 尿 & リ & ズ & 尿 & 㙓 & F & 發 \\
\hline 何 & & 發 & $\zeta$ & 3 & $\Rightarrow$ & & 往 & 可 & 後 & $=$ & 利 & 褰 & $y$ & $=$ & 猩 & 病 \\
\hline r & & シ & 死 & 婜 & 苪 & & \& & ナ & I & 闆 & 尿 & 腎 & 輕 & シ & 縕 & $\exists$ \\
\hline N & & 其 & 己 & 炎 & 初 & & 졸 & y & 不 & 2 & $=$ & 炎 & 度 & $\bar{\gamma}$ & 美 & $y$ \\
\hline 治 & & 五. & ナ & 患 & $=$ & & 3 & 更 & 良 & 殊 & 關 & $\Rightarrow$ & + & 敗 & 傳 & $\equiv$ \\
\hline 療 & & 名 & y) & 者 & 發 & & 輕 & $=$ & \& & $=$ & シ & 發 & N & 血 & 染 & $\overrightarrow{+}$ \\
\hline 法 & & $=$ & ₹ & 中 & $\pi$ & & 症 & 重 & 2 & 腐 & $\bar{\gamma}$ & $\pi$ & 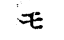 & 症 & 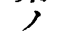 & 日 \\
\hline$\exists$ & & 於 & + & + & 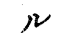 & & ナ & $\neq$ & $\exists$ & 敗 & > & $w$ & , & 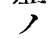 & 輕 & 前 \\
\hline 以 & & $\bar{\gamma}$ & 八 & $\therefore$ & 猖 & & $N$ & $\rightarrow$ & P & 性 & 種 & 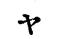 & $P$ & 第 & 重 & $=$ \\
\hline $\bar{\gamma}$ & & $\rightarrow$ & 名 & 名 & 紅 & & 猩 & 尿 & ㅈ & $=$ & ४ & 大 & $y$ & $=$ & 1 & 發 \\
\hline x & & 之 & $=$ & $\rightarrow$ & 熱 & & 紅 & 堇 & $\approx$ & シ & $\therefore$ & 抵 & 豫 & 第 & $=$ & シ \\
\hline 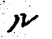 & & $\exists$ & 於 & 死 & 蛋 & & 㪇 & 柾 & シ & $\bar{\gamma}$ & 定 & 撥 & 後 & 工 & > & 是 \\
\hline$€$ & & 慢 & $\bar{\gamma}$ & 亡 & 百 & & $=$ & $\Rightarrow$ & 又 & 活 & $F$ & 熱 & $\therefore$ & 日 & - & $\eta$ \\
\hline 之 & & 性 & 八 & シ & 尿 & & 來 & 併 & 浮 & 穢 & ラ & シ & 腎 & 中 & 定 & 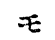 \\
\hline$\exists$ & & 筒 & $z$ & 其 & r & & $N$ & 發 & 穈! & 咖 & $x^{*}$ & 此 & 炎 & $=$ & $\gamma$ & 第 \\
\hline 避 & & 炎 & $=$ & 他 & 全 & & 7 & z & $E$ & 啡 & & 熱 & ノ & 死 & 關 & 兵 \\
\hline ク & & $r$ & 接 & ' & $\eta$ & & $\gamma$ & $N$ & 之 & 褐 & & 高 & 發 & 七 & 係 & 日 \\
\hline$y$ & 脹 & 得 & 大 & 證 & 再 & , & リ & 真 & 疝 & 本 & & & $\approx$ & 復 & 變 & 可 \\
\hline 內 & $\Rightarrow$ & 女 & + & $\Rightarrow$ & $E^{*}$ & 소 & 漸 & 性 & 及 & 年 & & & $\overrightarrow{2}$ & 拨 & $\pi$ & 力 \\
\hline 科 & 輕 & $y$ & N & 駁 & 舊 & 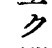 & ↔ & J & 腎 & 二 & & & $\underset{\Xi}{\Xi}$ & 絊 & $N$ & ラ \\
\hline 娂嘉 & 快 & 數 & 腎 & t & 說 & 機 & 其 & 疾 & 血 & 月 & (0) & & 2 & 粹 & $\rightarrow$ & $\pi^{2}$ \\
\hline 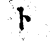 & $t$ & 多 & 開 & y & 7 & 能 & 意 & 病 & $>$ & 伯 & 腎 & & & 植 & 之 & 之 \\
\hline \$ & シ & ) & 切 & 氏 & 興 & 的 & 味 & r & 古 & 林 & 新 & & 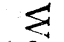 & 40 & 7 & $=$ \\
\hline テ & $x$ & 篡 & 術 & $\rightarrow$ & サ & + & $\exists$ & 爲 & 萊 & 內 & & & 8 & 畣 & 持 & 反 \\
\hline 之 & Z & 合 & 7 & 一 & ע & $\nu$ & 失 & シ & $\exists$ & 科 & 筲 & & $\ddot{\circ}$ & 哀 & 續 & シ \\
\hline 7 & 外 & $=$ & 施 & 見 & ト & 痽 & 7 & . & y & 會 & 血 & & $\vec{\omega}$ & $\overrightarrow{4}$ & 性 & 水 \\
\hline 賛 & 科 & 於 & シ & 1. & セ & 痛 & $=$ & 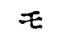 & 知 & $=$ & 五 & ) & 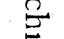 & $\stackrel{H}{=}$ & 案 & 腫 \\
\hline Ł & 家 & $\bar{\gamma}$ & 而 & 機 & シ & 及 & 至 & 診 & 悉 & 於 & 臤 & \& & & 洁 & 臥 & 及 \\
\hline シ & 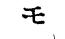 & $\therefore$ & $y$ & 能 & $\pi^{\prime}$ & 出 & $v$ & 縞 & 七 & テ & 肖 & (-) & $\overrightarrow{0}$ & 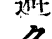 & (107 & 尿 \\
\hline 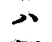 & イ & 解 & 조 & 性 & ヤ & 血 & $y$ & 學 & ラ & ゼ & 炎 & 粃 & 이 & VI & 沺 & 䓯 \\
\hline 獨 & ス & 剖 & ク & 腎 & 1 & F & 近 & ; & $v$ & ナ & $=$ & (1) & & 7 & 瓦 & 性 \\
\hline$y$ & ラ & 切 & 警 & 血 & $x$ & $N$ & 時 & 進 & タ & 1 & 哺 & $\hat{8}$ & 2 & 得 & 㙕 & ノ \\
\hline$f$ & $x$ & 開 & $\eta$ & I & z & 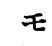 & 3 & 步 & N & 卜 & 尔儿 & & & น & ' & 發 \\
\hline ") & $\Omega$ & $=$ & べ & 多 & 、 & ノ & $\nu$ & シ & 病 & 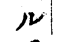 & $\bar{\tau}$ & & $\stackrel{\vec{c}}{\vec{c}}$ & シ & 嚴 & 生 \\
\hline$=$ & 氏 & 由 & $\neq$ & $\Rightarrow$ & イ & 之 & 厶 & $\bar{z}$ & 候 & 氏 & & & & 1 & 重 & 亚 \\
\hline 1 & 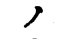 & 广 & 發 & , & ス & $\gamma$ & n & 精 & ナ & יו & & & & & $F$ & $\equiv$ \\
\hline 2 & 方 & 腎 & 悓 & 第 & ラ & . & $\nu$ & 妙 & y & 述 & & & & & 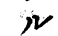 & 腎 \\
\hline 氏 & 法 & ; & 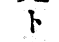 & 合 & I & P & $\Omega$ & $\tilde{r}$ & 以 & 心゙ & & & & 전 & 牛 & 氺 \\
\hline$\gamma$ & $\Rightarrow$ & 血. & 成 & $\Xi$ & $n$ & 為 & 氏 & ナ & 前 & $\bar{\gamma}$ & & & & 5 & 军 & , \\
\hline 2 & 是 & 積 & 績 & 於 & 氏 & : & > & $v$ & 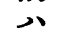 & 日 & & & & $\vec{n} \cdot$ & 食 & 慢 \\
\hline ノ & 認 & 性 & 阝 & $\bar{\gamma}$ & 八 & 以 & 腎 & $=$ & 之 & $\eta$ & & & & $\overrightarrow{1}$ & 及 & 性 \\
\hline ミ & セ & 腫 & $\exists$ & 廣 & 此 & $\bar{\gamma}$ & 臟 & 至 & 7 & 腎 & & & & $\overrightarrow{0}$ & 其 & $=$ \\
\hline
\end{tabular}




\section{七一二錄抄誌雜會究研事醫堂天順}

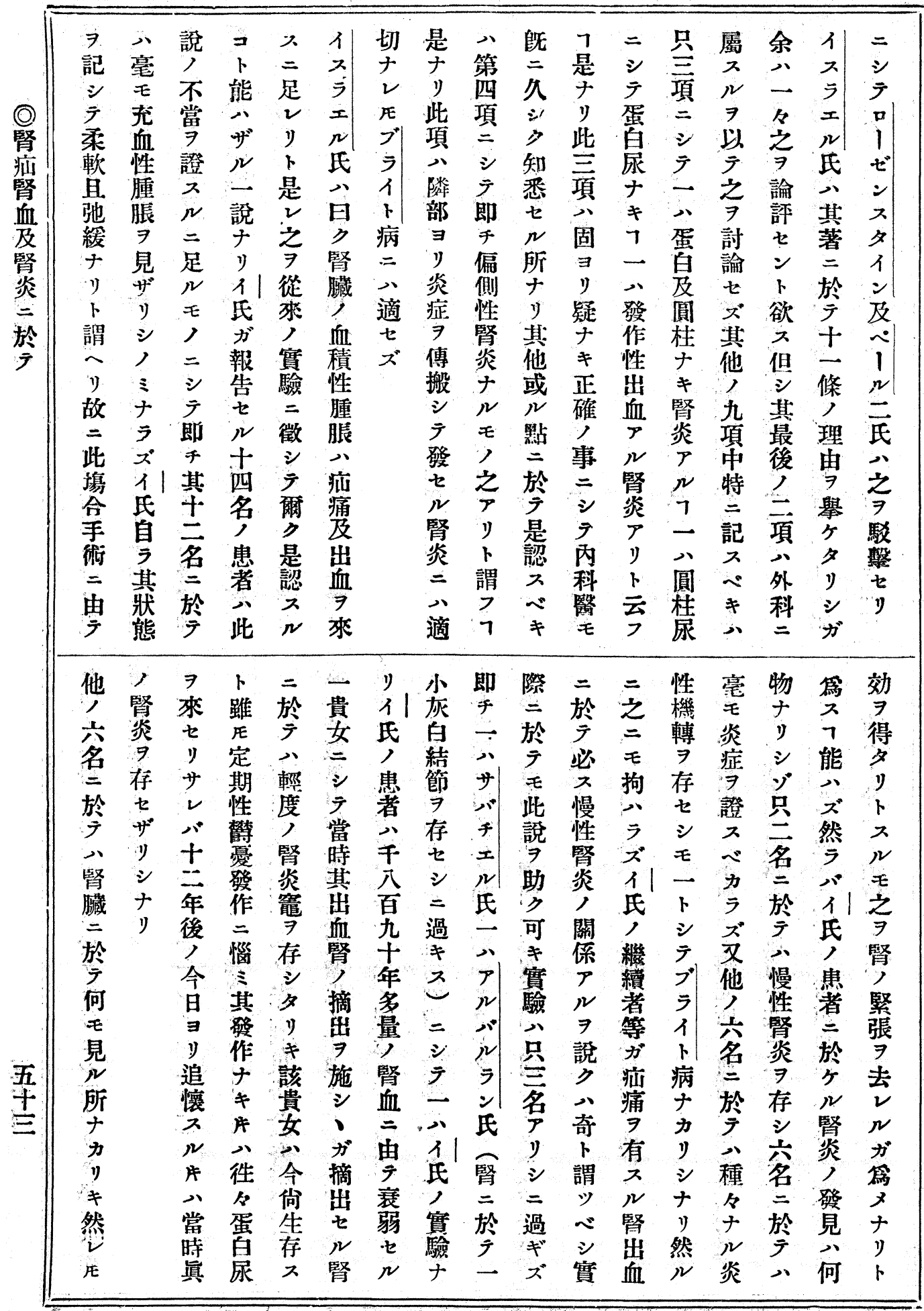


號一十五百三第誌椎會究研事醫堂天順 $\quad$ 八一二

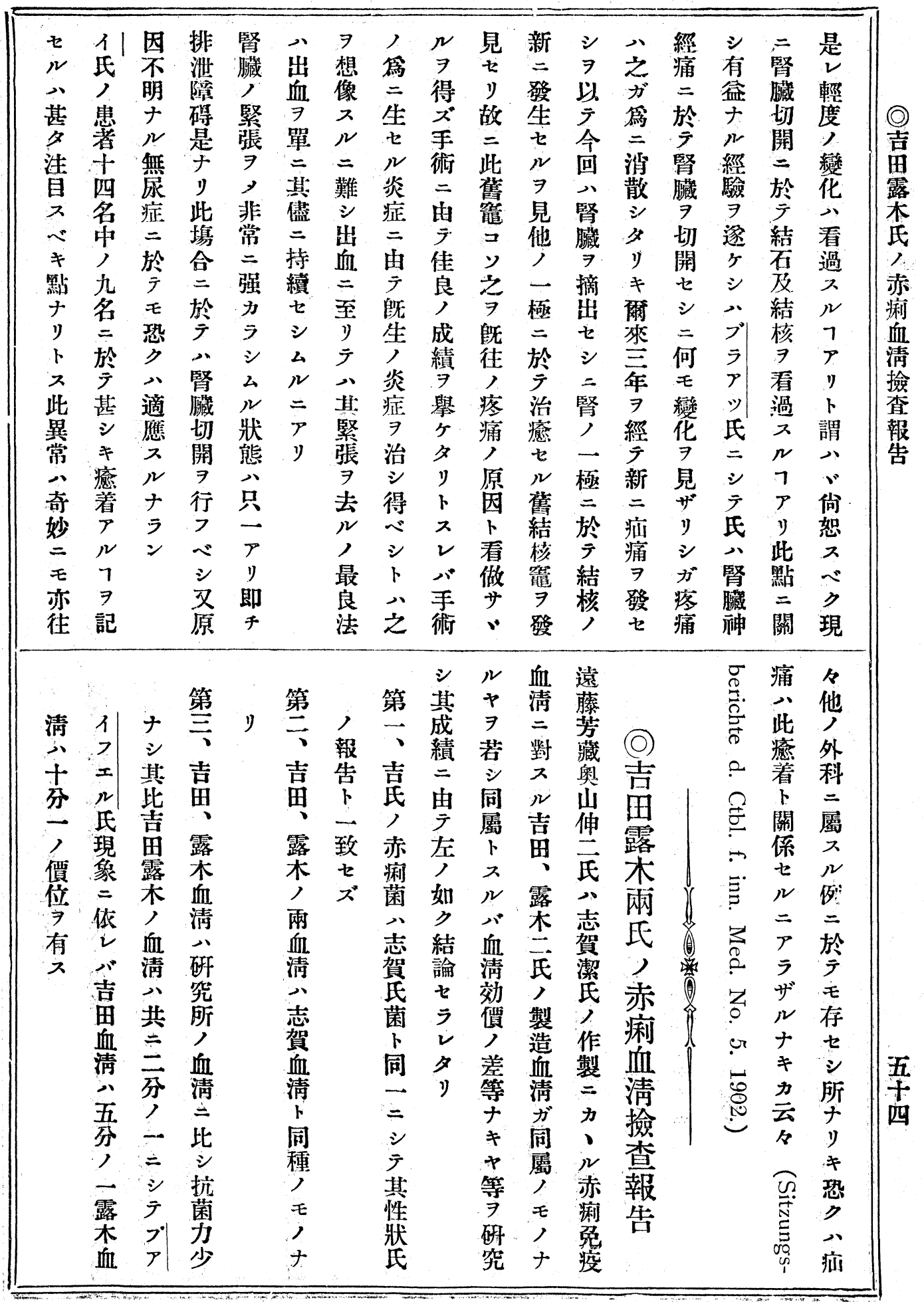




\section{九二二錄抄誌雜會究研事醫堂天順}

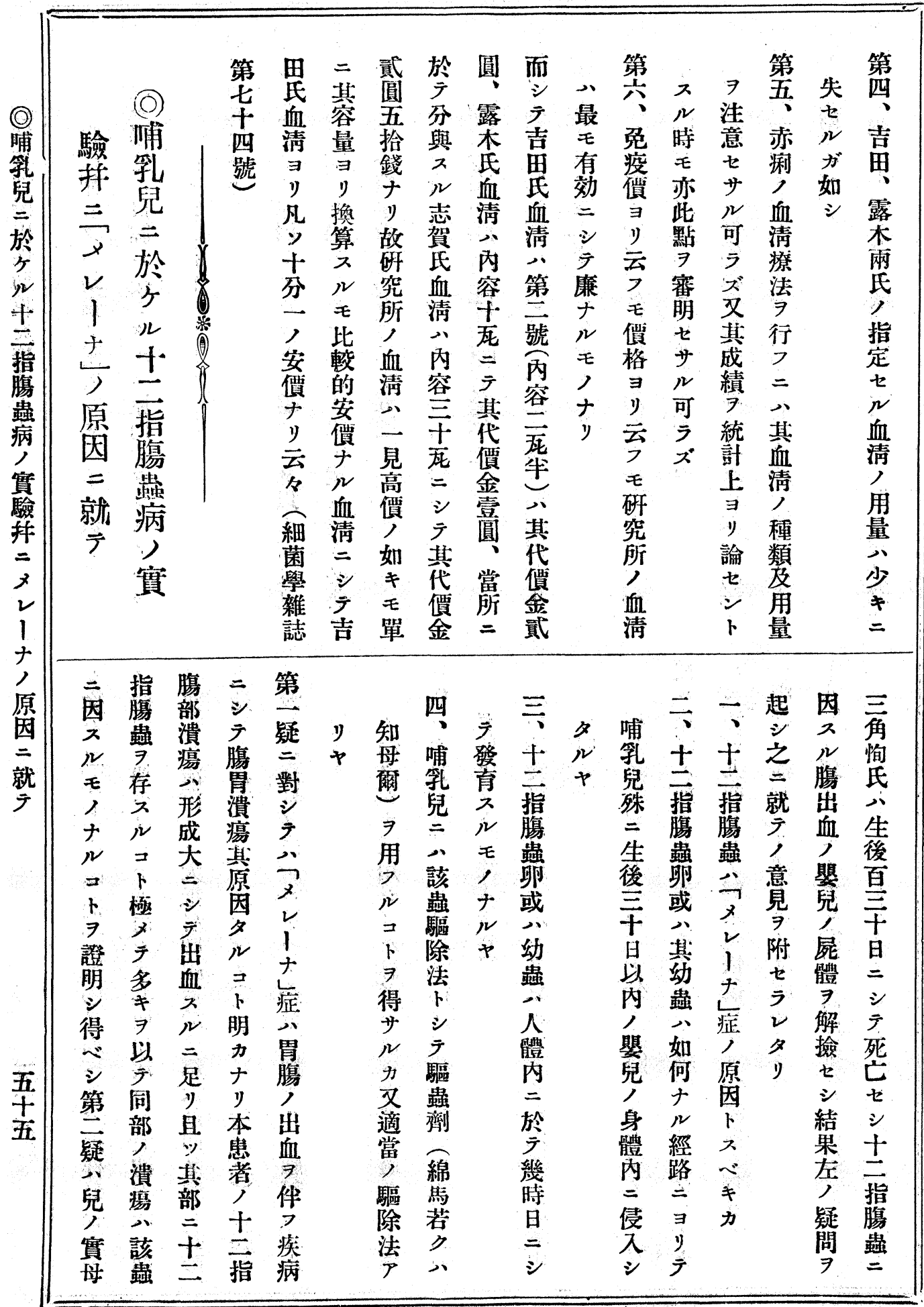


號一十五百三第誌雜會究研事醫堂天順 O二=

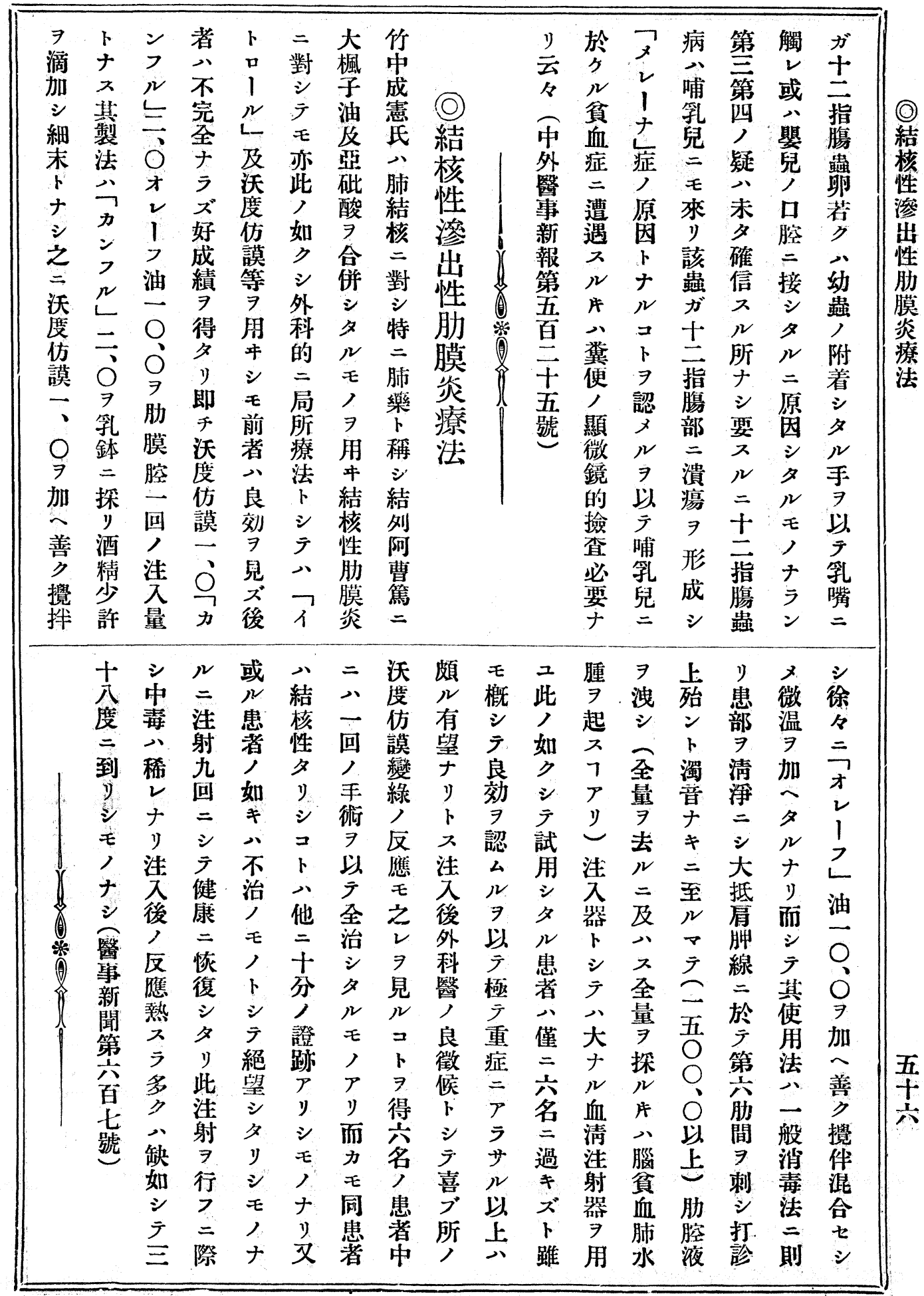


-二二錄抄誌雜會究研事醫堂天順

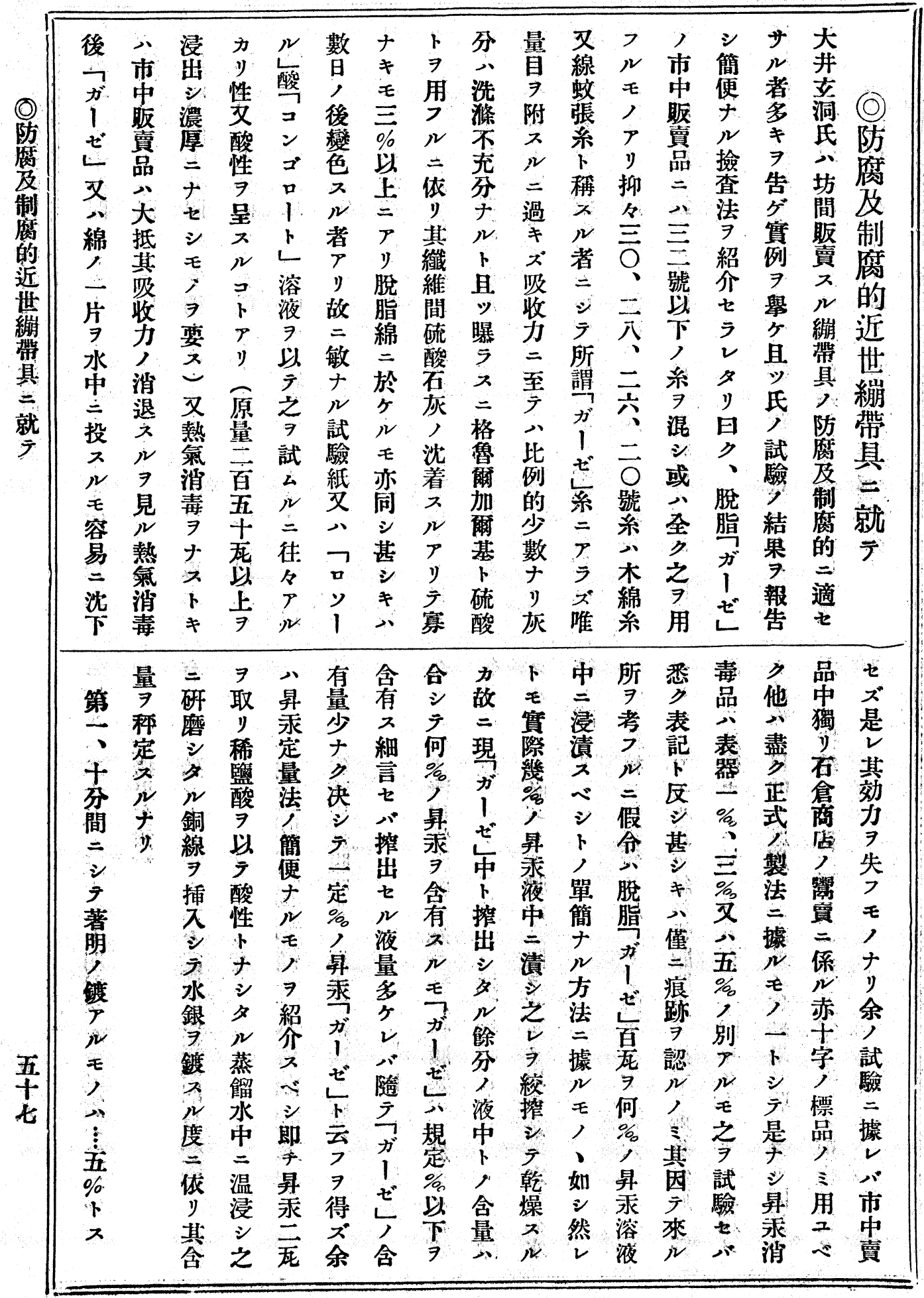


號一十五百三第誌雜會究研事醫堂天順二二=

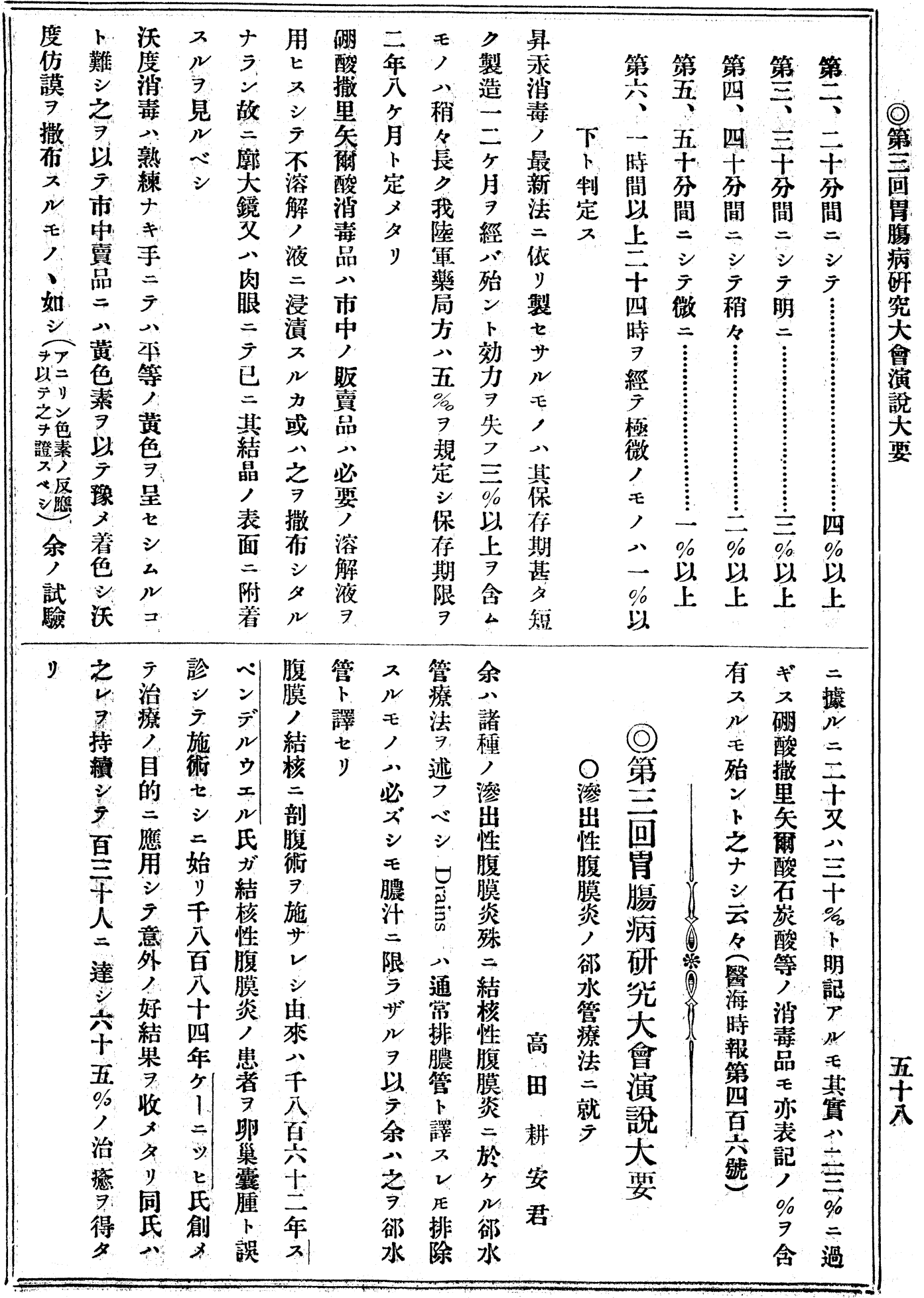


三二三錄抄誌雜會究研事醫堂天順






\section{號一十五百三第誌雓會究研事醫堂天順四二二}

\begin{tabular}{|c|c|c|c|c|c|c|c|c|c|c|c|c|c|c|c|c|}
\hline 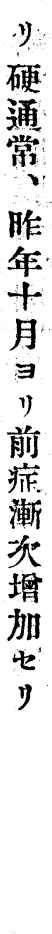 & 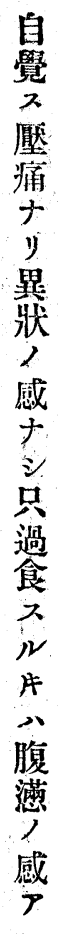 & 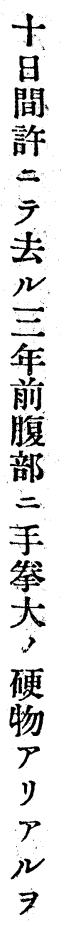 & 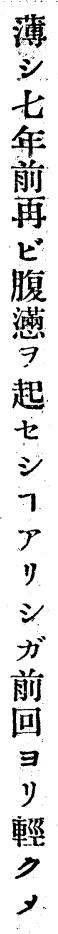 & 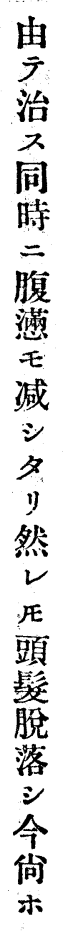 & 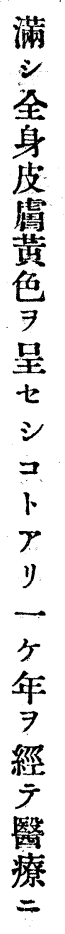 & 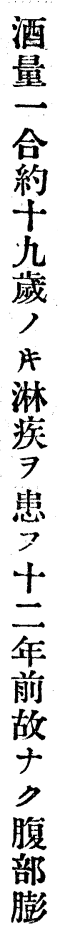 & 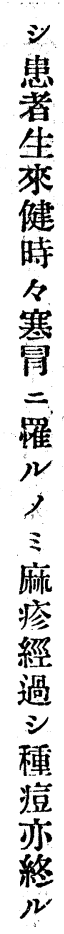 & 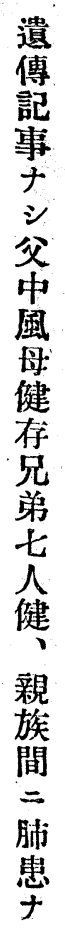 & 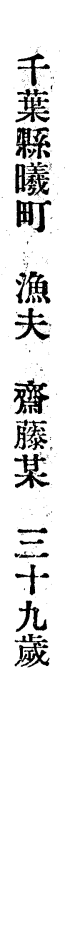 & $\begin{array}{l}セ \\
\nu\end{array}$ & 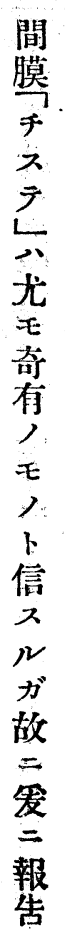 & 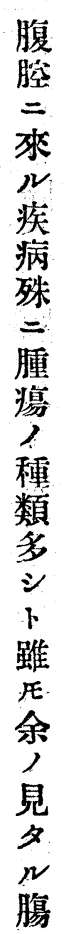 & $\begin{array}{l}\text { 寺 } \\
\text { 田 } \\
\text { 織 } \\
\text { 尾 } \\
\text { 君 }\end{array}$ & 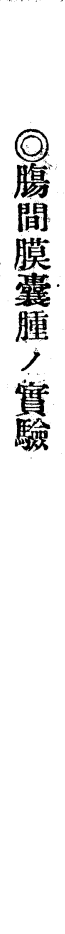 & & 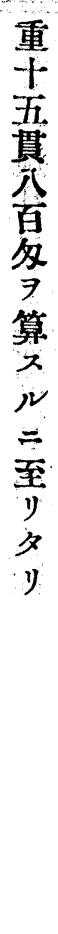 \\
\hline 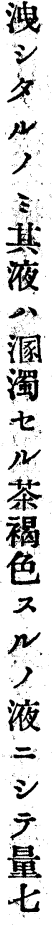 & 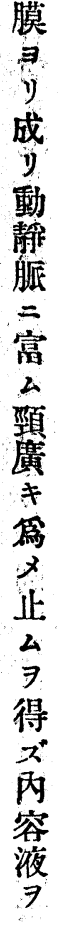 & 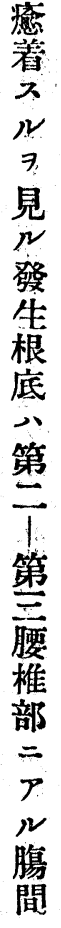 & 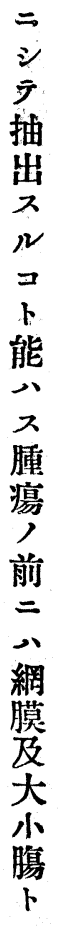 & 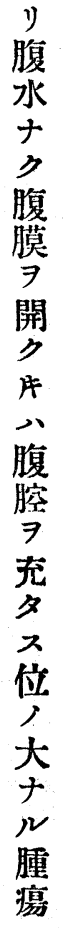 & 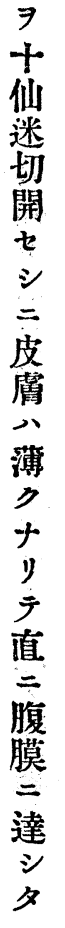 & 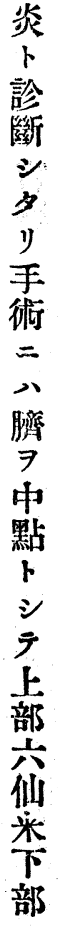 & 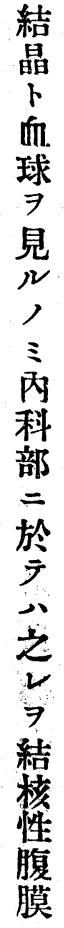 & 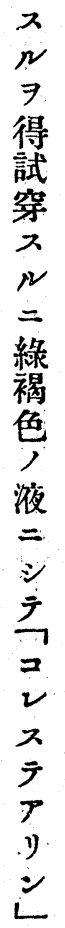 & 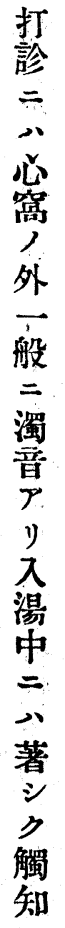 & 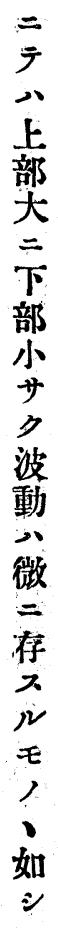 & 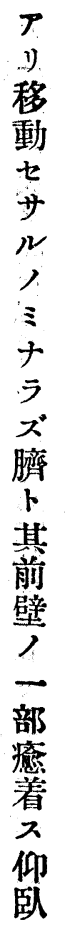 & 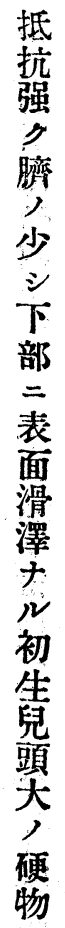 & 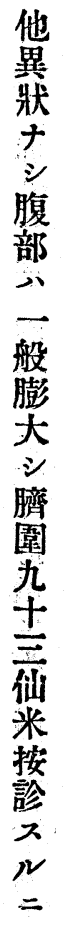 & 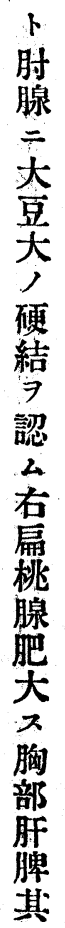 & 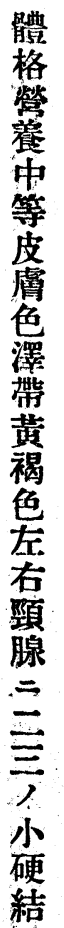 & 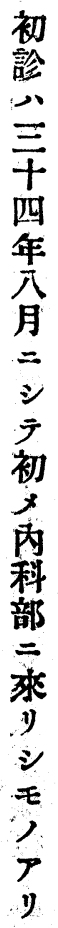 \\
\hline
\end{tabular}


二 三 刘氏 斯診 $\exists$ 七 尿

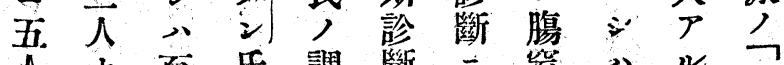

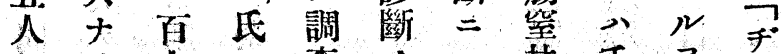

第 $=$ 少

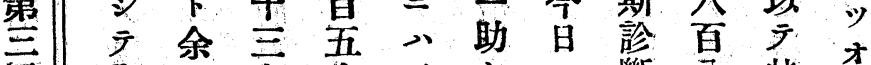

回

胃

膓

病:

研

究

态

演

蕞

要

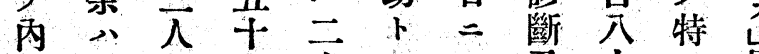

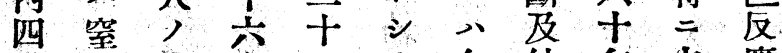

人扶内人元血結年之應

二斯陽”名用清核 $匚 7$ ․

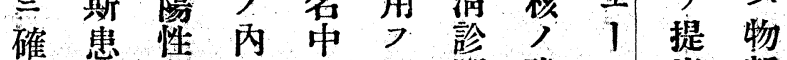

證著, 百二ル斷豫 ル出新

$\mathrm{t}=\mp \stackrel{x}{t}$

余接古五向值實就

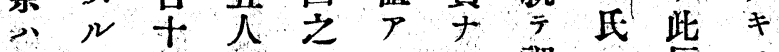

臨, 一西 $\ni ル n$ 調二质正

機人鄉證ナ

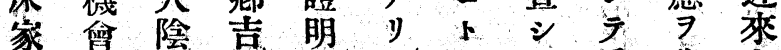

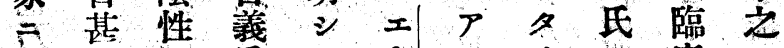

堅夕夕氐夕1 12 》床 $=$ k

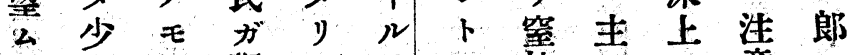

絕ナ人調 プリモ扶三三意

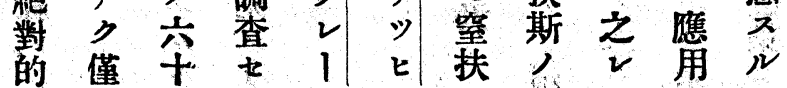

君

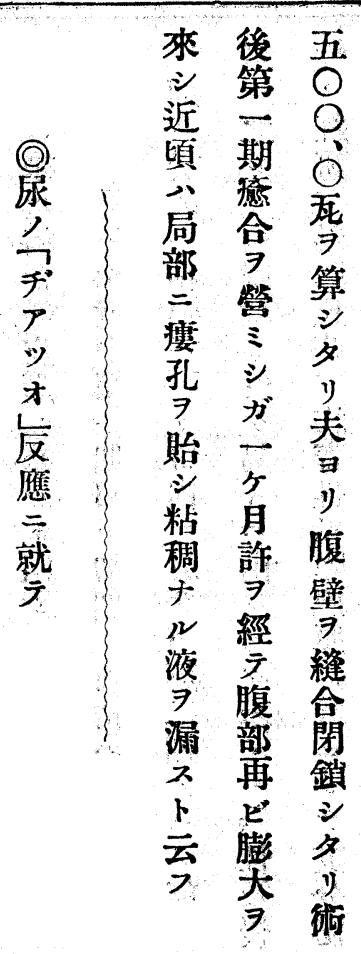

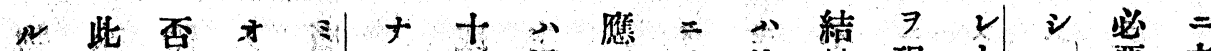

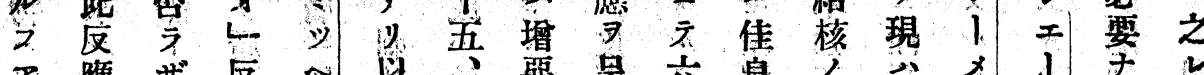

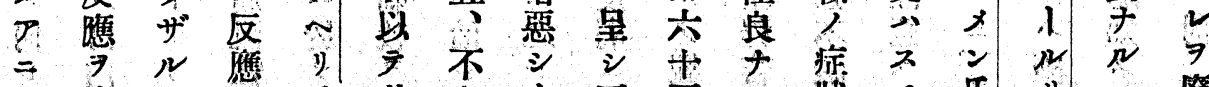

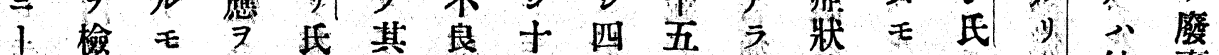

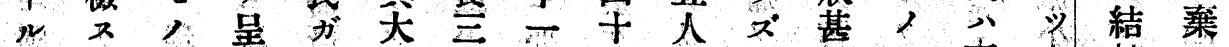

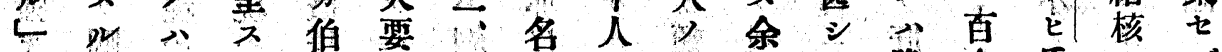

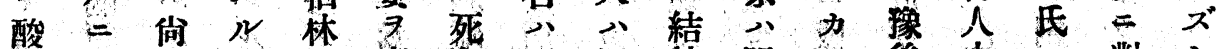

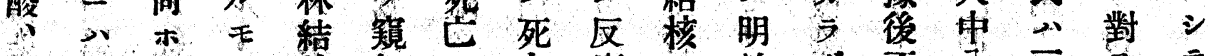

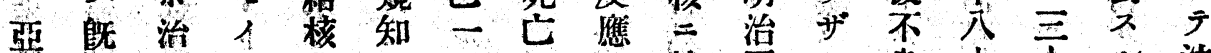

硝 $=$ 療

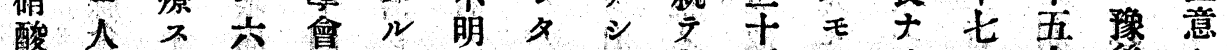

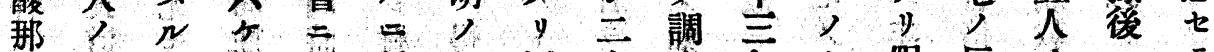

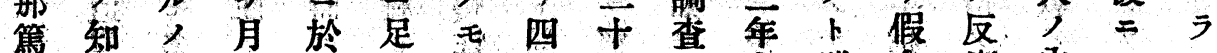

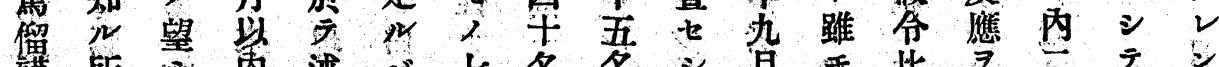

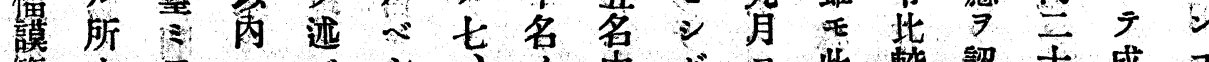

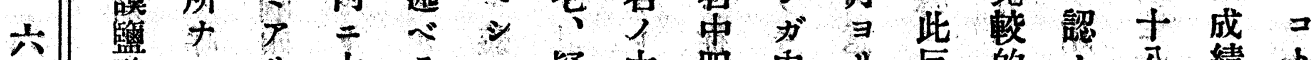

十酸 $y$ 大

混試云死

液 驗

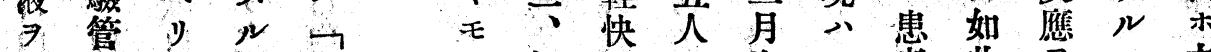

置 $=$ チ

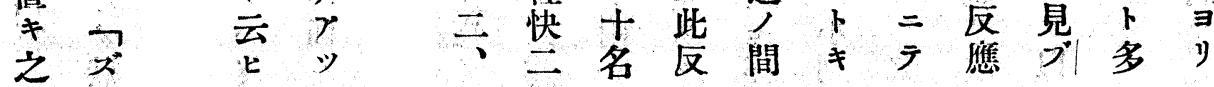




\section{號一十五百三第誌雜會究研事醫堂天順 六二二}

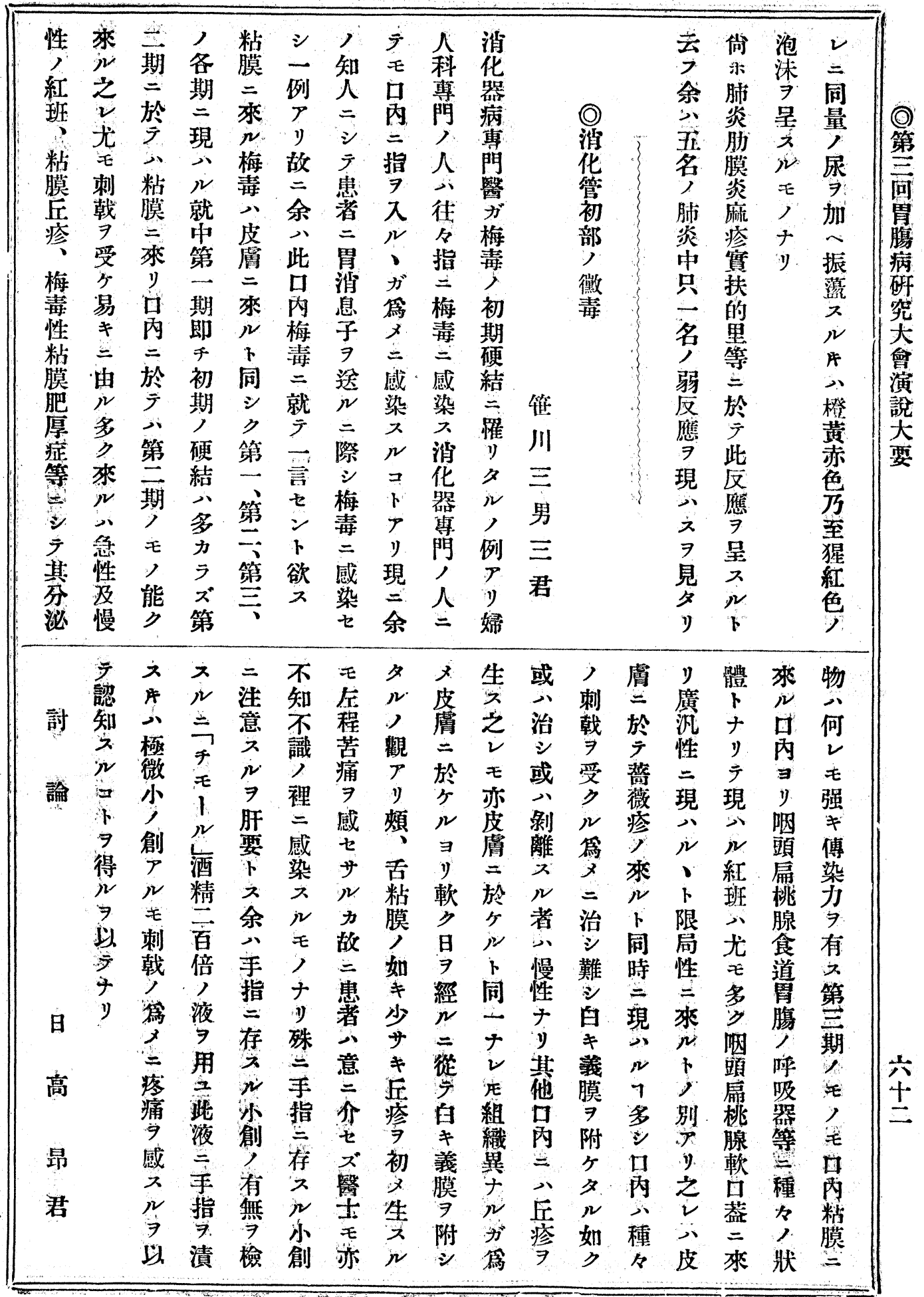




\section{七二錄抄誌雜會究研事醫堂天順}

(ㅇ)

會 常 $=r$ 言 專余府手士

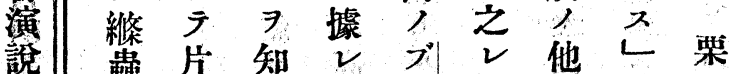

要

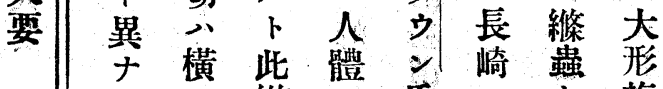
縧 $=$ 氏 $=$ 複

點 廣 蟲此二於異殖

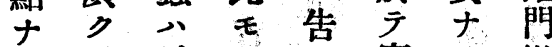

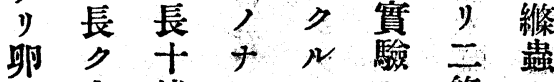

剥必力管余

尹 ズ 如 厂

試胃少本胃

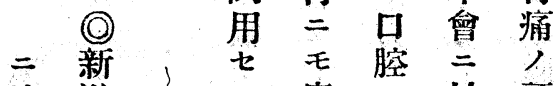

亏 病人於頑

レ 毒 梅 天固

ン. 毒 述

马傳 $t 八$

卜 搬 $ル \& モ$

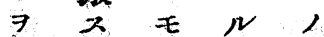

望 $N$, $=$

公卉占

今 如 $>$ 剝

厶 斯 y 7

故 劇 $\neq$ 與

烈 今会

碩 符

固 ル川治

角君

胃, 久

痛

$=\pi \vec{v}$

沃 D济

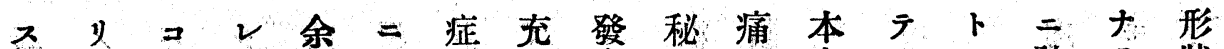

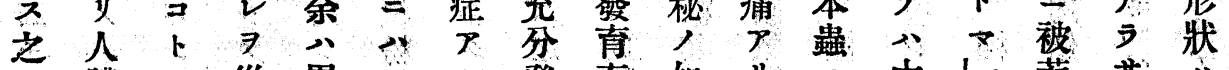

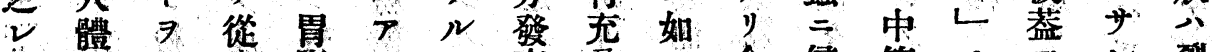

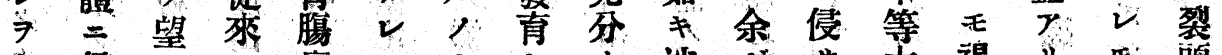

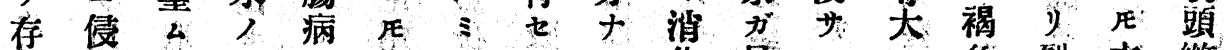

入入盖

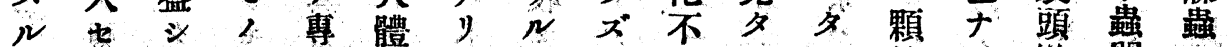

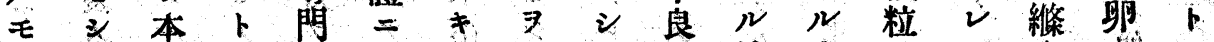

, 者邦輕 $\&$ -

F t

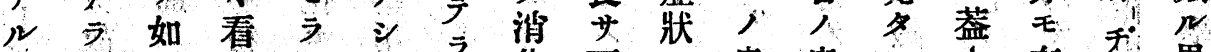

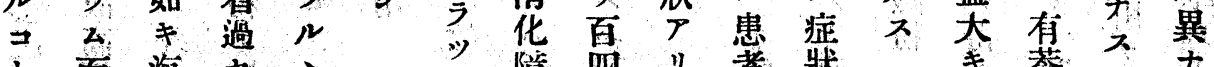

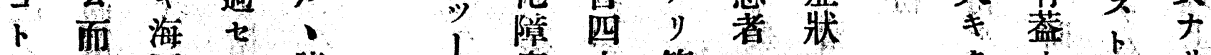

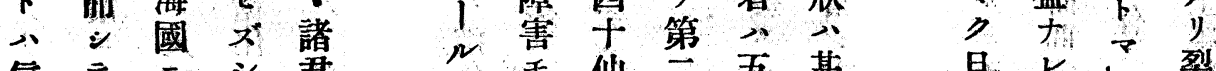

信 $=$ 君次无仙五甚

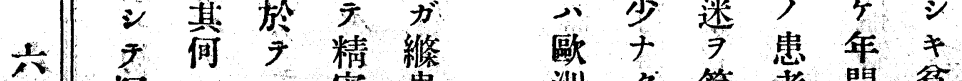

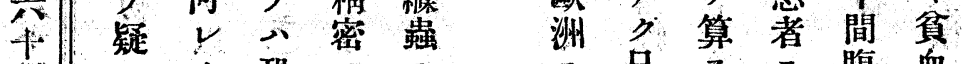

三 , 恐 $==$ 只

* 魚 检遭於下㕣於痛二

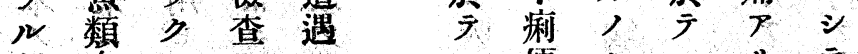

所虫 $\rightarrow$ t $飞$ 便

ナ二魚 $ラ$ 動秘 卵綘下强

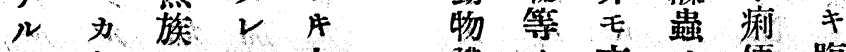

习. 必 $\exists=$ 之

㣂 亦, 便 腹

且 $v \stackrel{\checkmark}{\llcorner}$

臀褐 如

方色尘

笑少褐二

七。色在

$y \geqslant \exists \quad$

内肺有

容 7 年

三卡褐 
號一十五百三第誌雜會究研事醫堂天順分三二

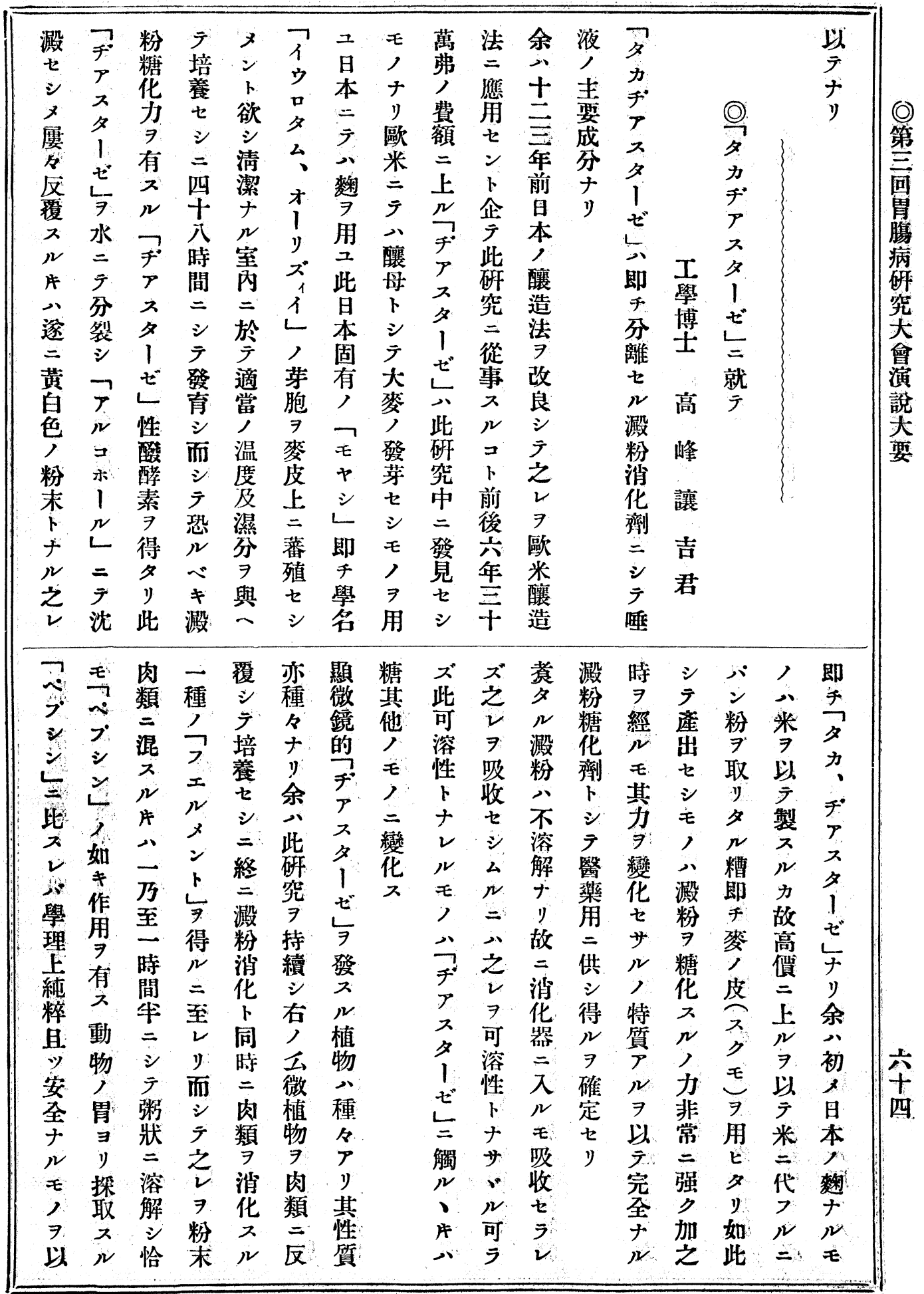


无二二錄抄誌雜會究研事醫堂天順

\begin{tabular}{|c|c|c|c|c|c|c|c|c|c|c|c|c|c|c|c|c|}
\hline 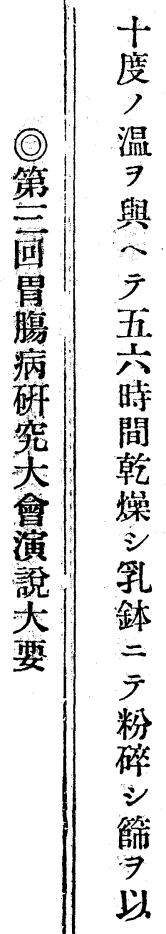 & 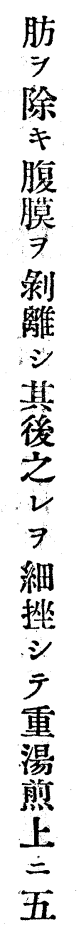 & 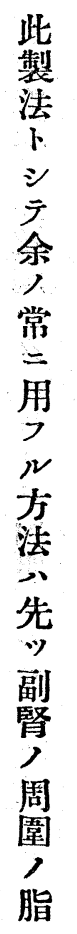 & 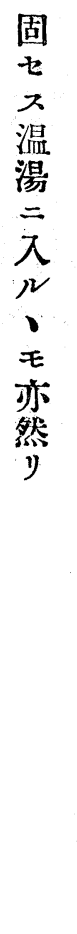 & 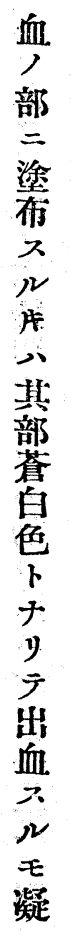 & 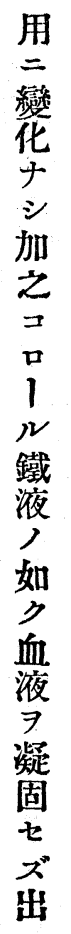 & 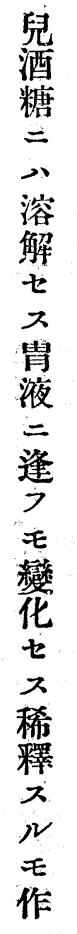 & 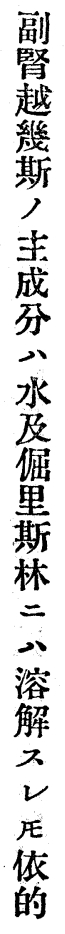 & 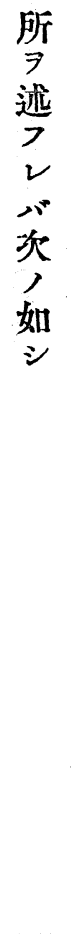 & 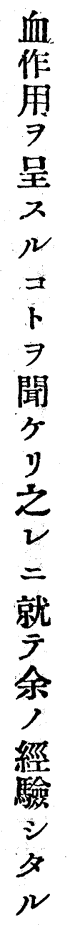 & 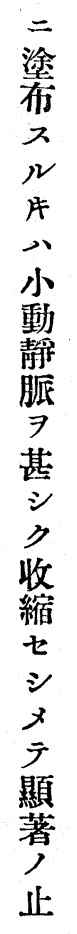 & 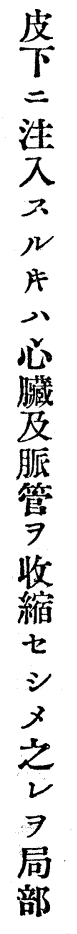 & 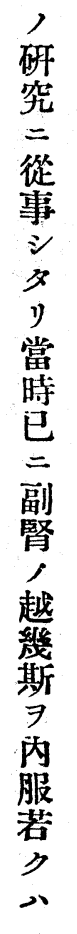 & 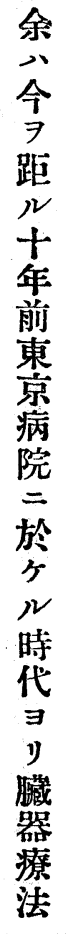 & $\begin{array}{l}\text { ○) } \\
\text { 副 } \\
\text { 腎 } \\
\text { 越 } \\
\text { 畿 } \\
\text { 斯 } \\
\text { 圭 } \\
\text { 圭 } \\
\text { 效 } \\
\text { 用 }\end{array}$ & & 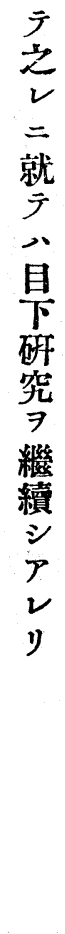 \\
\hline $\begin{array}{l}y \\
\text { y } \\
\text { v } \\
+ \\
y\end{array}$ & 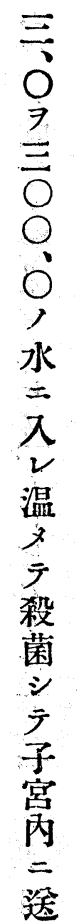 & 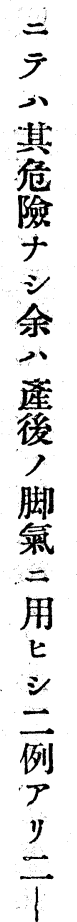 & 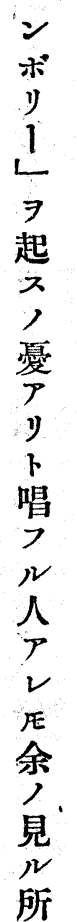 & 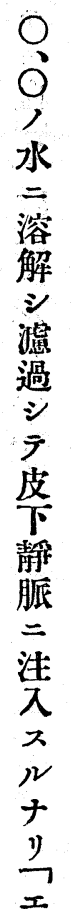 & 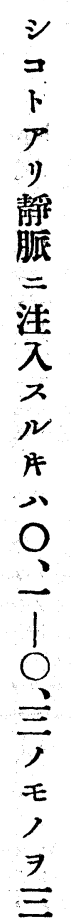 & 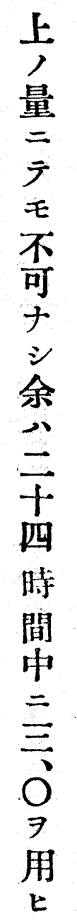 & 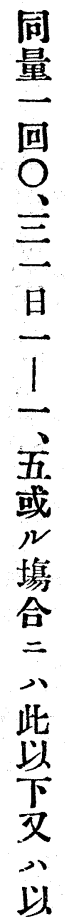 & $\begin{array}{l}\text { 加 } \\
> \\
N \\
\text { A } \\
\text { 更 } \\
= \\
\text { 娶 } \\
\text { ナ } \\
\text { y }\end{array}$ & 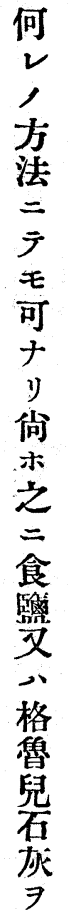 & 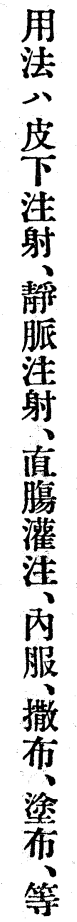 & 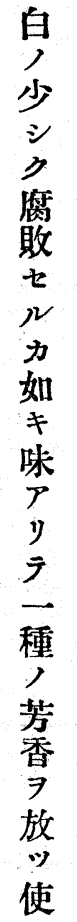 & 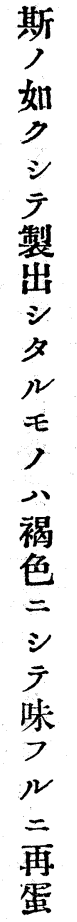 & 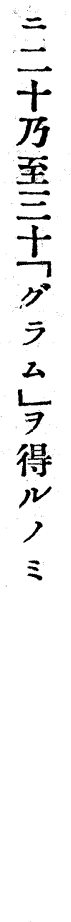 & 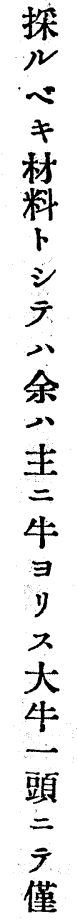 & 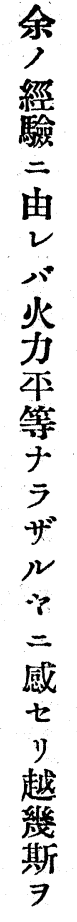 & 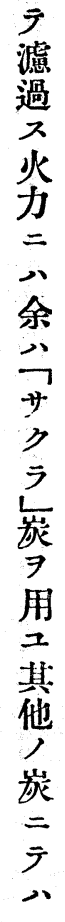 \\
\hline
\end{tabular}


號一十五百三第誌雜會究研事醫堂天順

\section{$O \equiv 二$}

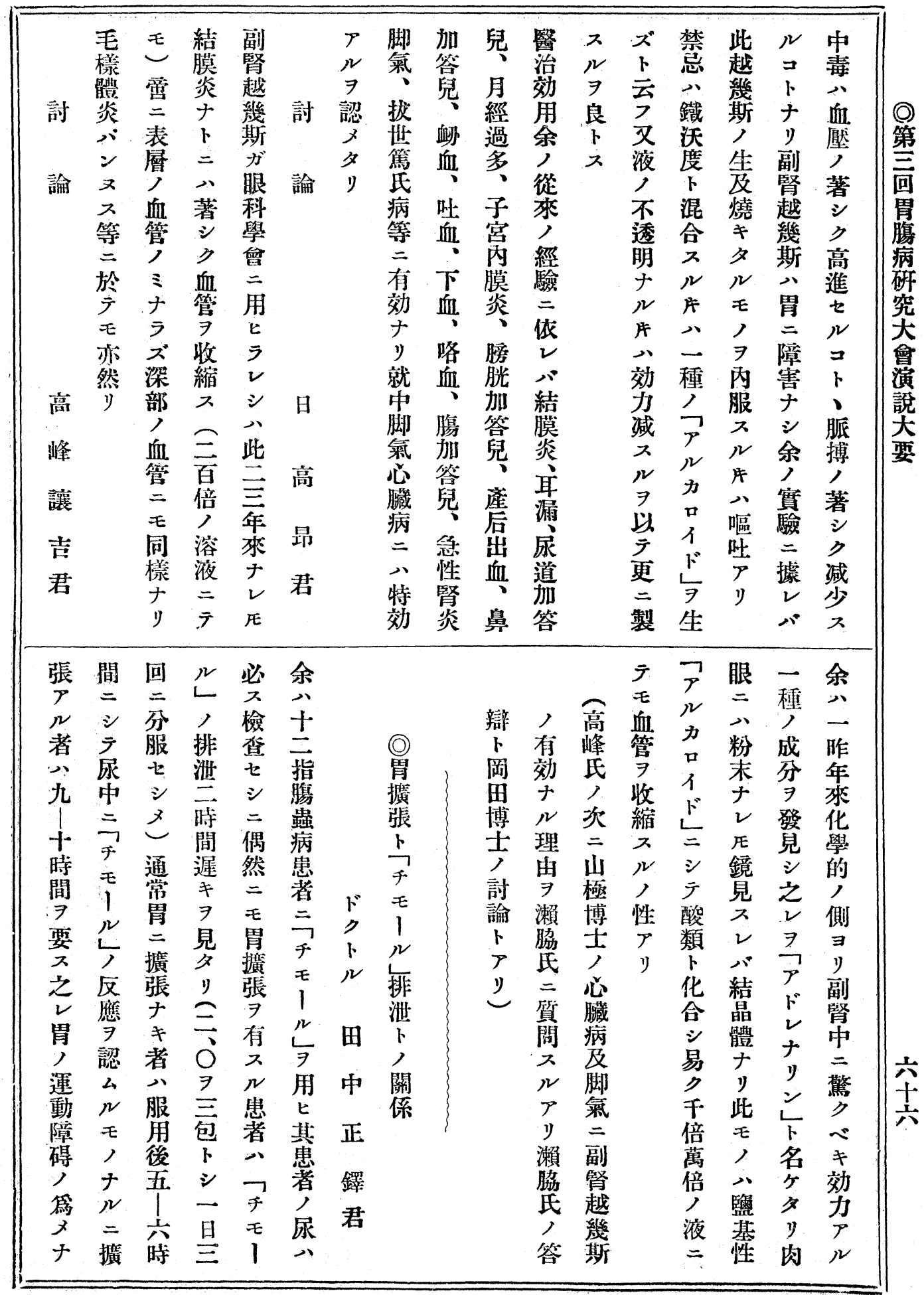


一三二 錄抄誌雜會究研事醫堂天順

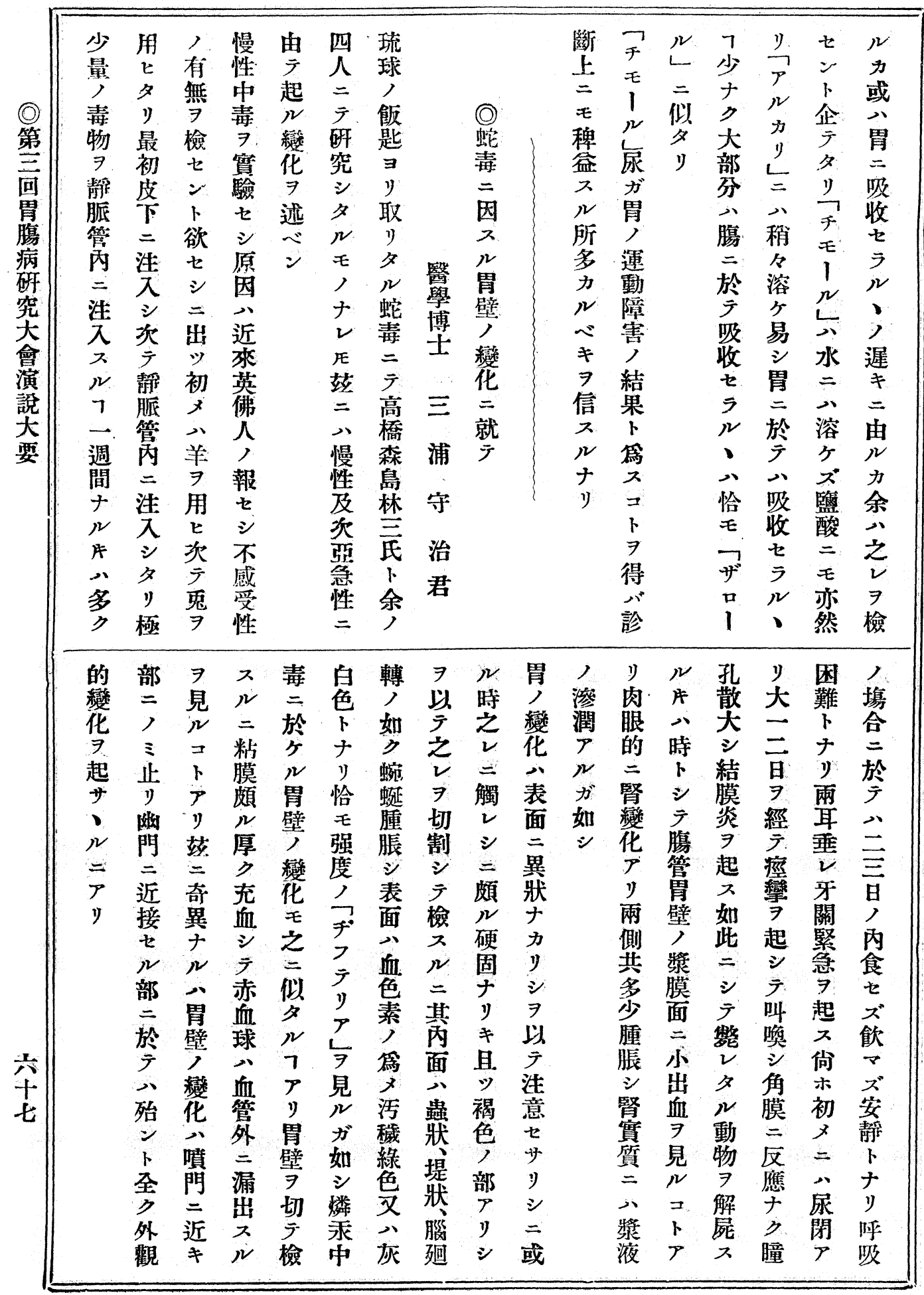


號一十五百三第誌雜會究研事醫堂天順 二三二

\begin{tabular}{|c|c|c|c|c|c|c|c|c|c|c|c|c|c|c|c|c|}
\hline 疼 & 第 & ナ & 第 & 診 & 床 & 欲 & $N$ & 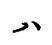 & 区 & $v$ & N & 發 & $\exists$ & 食 & & \\
\hline 痛 & 一 & $\neq$ & $\equiv$ & 七 & 的 & ス & 所 & 比 & 同 & $\mathscr{E}$ & ) & 生 & 起 & 䲕 & & \\
\hline$\gamma$ & V & 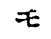 & $\rightarrow$ & ラ & $=$ & 2 & $\gamma$ & 較 & 神 & 二 & 部 & $\pi$ & $\pi$ & 猜 & & \\
\hline$ル$ & 四 & ノ & 聲 & ル & $\rightarrow$ & ナ & 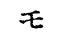 & 的 & 經 & 5 & 是 & $N$ & 原 & 寒 & & (0) \\
\hline 故 & + & ナ & 音 & $\checkmark$ & 珍 & リ & ノ & 多 & $J$ & 年 & F & 部 & 因 & 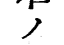 & & - \\
\hline$\Rightarrow$ & 三 & $y$ & 嗄 & 手 & $\bar{j}$ & 其: & 二 & 力 & 麻 & 間 & $y$ & $\stackrel{\partial}{\equiv}$ & 3 & 原 & & - \\
\hline 以. & $\bar{f}$ & $\neq$ & 嘶 & 拳 & シ & $\because$ & $\equiv$ & 3 & 猈 & $=$ & 就 & 所 & 牛 & 因 & & $\overrightarrow{\text { 珍 }}$ \\
\hline$\overline{\bar{\gamma}}$ & J & & 呼 & 大 & 其 & 八 & 7 & ズ & $\Rightarrow$ & + & 中 & $\gamma$ & 分 & $\rightarrow$ & & 奇 \\
\hline 余 & 魚 & & 吸 & > & $=$ & 多 & 得 & 余 & 以。 & 公 & 第 & y & 以 & 尤 & & ナ \\
\hline$\zeta$ & 商 & & 因 & 前 & $\rightarrow$ & 發 & 夕 & ガ & $\bar{j}$ & 1 & - & 喉 & 上 & 乇 & 㗨 & $N$ \\
\hline 許 & & & 難 & 頸 & 化 & 性 & $N$ & 今 & シ & F & ノ & 頭 & $\exists$ & 多 & 锴 & 食 \\
\hline$=$ & 昨 & & $\zeta$ & 部 & 膿 & 癌 & $\exists$ & 述 & テ & 見 & 部 & $\jmath$ & 占 & $\Rightarrow$ & 學 & 渻 \\
\hline 來 & 早 & & 症 & $\jmath$ & 性 & $=$ & 以 & べ & 食 & 夕 & 最 & 後 & 厶 & 癌 & 博 & 䖽 \\
\hline$N$ & 春 & & 7 & $\vec{p}$ & 軟 & シ & $\overline{\bar{T}}$ & ン & 物 & y & 王 & 部 & 而 & 腫 & I & $=$ \\
\hline 診 & 頃 & & 以。 & 7 & 骨 & $\bar{z}$ & 之 & ト & 嘿 & 余 & 多 & 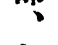 & $y$ & $=$ & & 就 \\
\hline ᄌ & $\exists$ & & $\bar{\gamma}$ & t & 脾 & 屍 & $v$ & 欲 & $T$ & 1 & シ & 氣 & 食 & $P$ & 岡 & $\bar{\gamma}$ \\
\hline 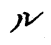 & y & & 來 & $\begin{array}{l}\text { t } \\
\text { x }\end{array}$ & 炎 & 體 & $\exists$ & x & 困 & 診 & 故 & 勞 & 檤 & $y$ & 用 & \\
\hline$=$ & 咽 & & リ & 는 & ' & $=$ & 榙 & $N$ & 難 & 䕓 & $=$ & 3 & $=$ & 癌 & 田 & 槚故 \\
\hline 左 & 喉 & & シ & $\exists$ & 甲 & M & 君 & 八 & $\exists$ & 所 & 余 & 分 & 於 & 腩 & 和 & 供江 \\
\hline$J$ & 部 & & $モ$ & 以. & 狀 & 往 & $=$ & 通 & 以 & $=$ & J & 岐 & $\bar{\tau}$ & $\rightarrow$ & $x=$ & 覽兆 \\
\hline 扁 & $=$ & & 嚾 & $\overline{\bar{\gamma}}$ & 軟 & 今 & 報 & 常 & テ & 來 & 專 & 部 & 好 & 䆵 & - & 岂 \\
\hline 桃 & 䓵 & & $T$ & 來 & 骨 & $\gamma$ & 告 & 多 & 楸 & יו" & 門 & 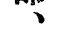 & $\overline{\bar{\gamma}}$ & $=$ & 郎 & \\
\hline 腺 & T & & 因 & ル & 炎 & 2 & Ł & $\Rightarrow$ & $n$ & 多 & 科 & 胃 & 癌 & 此 & 聿 & \\
\hline$=$ & 時 & & 難 & $\mp$ & 卜 & E & ע & 見 & $\tau$ & 3 & 外 & $=$ & 厝 & 㷋 & 君 & \\
\hline$=$ & $=$ & & $\rightarrow$ & ノ & 誤 & 臨 & r & サ & ᄀ & $>$ & + & 入 & $\exists$ & 窄 & & \\
\hline 進 & 檢 & \$ & ノ & $v$ & セ & 上 & $=$ & 熱 & $\pi$ & 第 & ス & 本 & p & 前 & 肯 & 鍇 \\
\hline$\dot{B}$ & $x$ & リ & ミ & 1 & シ & 部 & 食 & 發 & 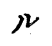 & $\Xi$ & & 贞 & 即 & $=$ & セ & 銅 \\
\hline ツ & N & シ & ナ & 食 & 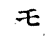 & $=$ & 道 & $\checkmark$ & $=$ & ' & & 度 & $\neq$ & 見 & ス & 货 \\
\hline ' & $=$ & $=$ & ラ & 道 & ノ & 魚 & I & 波 & 前 & $\equiv$ & & 癌 & 食 & $\not$ & $\ldots$ & 大 \\
\hline$P$ & 癌 & 食 & ズ & ト & ナ & 骨 & 入 & 動 & 頸 & + & & 及 & 道 & $N$ & 年 & 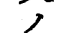 \\
\hline y & ナ & 道 & 湓 & ノ & 5 & 籍 & 口 & $P$ & 部 & 七 & & 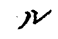 & $J$ & 扁 & $\exists$ & 硬 \\
\hline & $y$ & 上 & \$ & 連 & 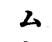 & 入 & 部 & ") & $=$ & 歲 & & 7 & 入 & 桃 & 經 & 性 \\
\hline & $\neq$ & 端 & 劇 & 絡 & P & シ & $\exists$ & 環 & 手 & $J$ & & 確 & 口 & 腺 & $\overrightarrow{\bar{J}}$ & 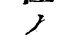 \\
\hline & 本 & $\exists$ & シ & $\rightarrow$ & 思 & $\bar{\gamma}$ & リ & 狀 & 拳 & 媂 & & $\not$ & 部 & 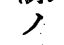 & 葆 & 潰 \\
\hline & 患 & リ & カ & 不 & E & 篇 & 密 & 軟 & 大 & 人 & & タ & $\exists$ & 潰 & T & 湟 \\
\hline & 者 & 下 & y & 明 & 切 & $x$ & 量 & 骨 & $ノ$ & 昨 & & リ & y & 瘍 & 不 & $\gamma$ \\
\hline & - & 方 & シ & ナ & 開 & $=$ & $=$ & 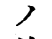 & 米 & 年 & & シ & 下 & $\rightarrow$ & 能 & $y$ \\
\hline & 今 & $=$ & 第 & y & Ł & 食 & 膿 & 前 & 球 & 五 & & モ & 方 & 依 & $\Rightarrow$ & 癌 \\
\hline & 䏌 & 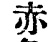 & $\overrightarrow{\overrightarrow{0}}$ & 然 & シ & 道 & 液 & 嗗 & 形 & 月 & & 手 & $=$ & 然 & 以 & 腫 \\
\hline & 木 & 色 & 院 & $\pi$ & $=$ & 周 & ノ & 膜 & 1 & 外 & & 術 & 蔓 & F & $\overline{\bar{\gamma}}$ & F \\
\hline & 生 & $\bar{J}$ & $=$ & $=$ & 四 & 葍 & 出 & 炎 & 腫 & 楸 & & 7 & 延 & シ & 再 & 診 \\
\hline & 存 & 硬 & 於 & 食 & 五 & 炎 & ツ & r & 物 & 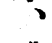 & & 施 & 七 & テ & ヒ & シ \\
\hline & z & $\neq$ & $\bar{J}$ & 道 & + & 7 & $N$ & 診 & $\gamma$ & 嚆 & & $\exists$ & $\mu$ & 存 & 秏 & $\bar{J}$ \\
\hline & 2 & 腫 & 食 & 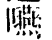 & 虎 & 作 & $\exists$ & シ & y & $T$ & & ス & 7 & シ & $\mu$ & 手 \\
\hline & $\mathcal{E}$ & 物 & 道 & $T$ & $\overline{7}$ & $y$ & 見 & 喉 & 疼 & 困 & & 克 & 見 & 披 & 此 & 術 \\
\hline & 目 & 7 & 切 & $\therefore$ & 洩 & 前 & N & 頭 & 痛 & 難 & & $\rightarrow$ & $N$ & 裂 & 時 & $\Rightarrow$ \\
\hline & F & 見 & 開 & 依 & $\overline{5}$ & $f_{j}$ & 䗆 & 7 & & $\exists$ & & ズ & 鏡 & 簐 & $=$ & 告 \\
\hline & 漸 & $N$ & $\exists$ & 然 & セ & $=$ & $\bar{J}$ & 檢 & 潮 & 訴 & & シ & 檢 & 骨 & 於 & ク \\
\hline & 次 & 之 & 施 & タ & リ & 侵 & 食 & $\pi$ & 紅 & 7 & & $\bar{J}$ & 上 & , & 5 & $N$ \\
\hline & 䞇 & 7 & シ & ル & 之 & 行 & 道 & N & & 診 & & 死 & 扁 & 後 & ה & $モ$ \\
\hline
\end{tabular}


三三二 書投誌雜會究研事醫堂天順

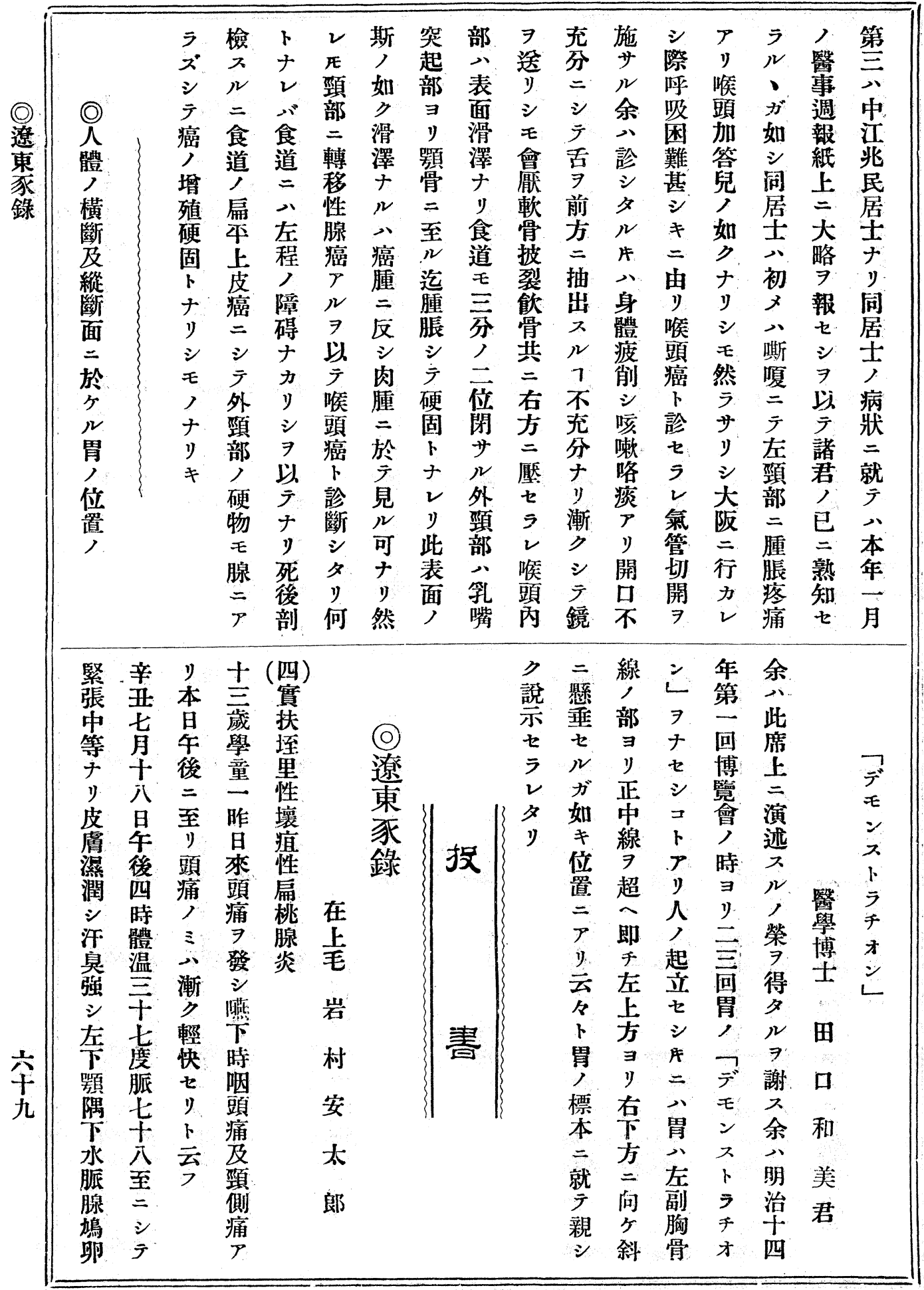

